Article

\title{
Could Mergers Become More Sustainable? A Study of the Stock Exchange Mergers of NASDAQ and OMX
}

\author{
Wenjing Xie ${ }^{1}$, João Paulo Vieito ${ }^{2} \mathbb{C}$, Ephraim Clark $^{3}$ and Wing-Keung Wong ${ }^{4,5,6, * \mathbb{C}}$ \\ 1 School of Economics and Finance, Shanghai International Studies University, Shanghai 200083, China; \\ leoxie818@shisu.edu.cn \\ 2 Escola Superior de Ciências Empresraiais, Instituto Politécnico de Viana do Castelo, 4930-600 Valença, \\ Portugal; joaovieito@esce.ipvc.pt \\ 3 Department of Accounting and Finance, Middlesex University London, London NW4 4BT, UK; \\ E.Clark@mdx.ac.uk \\ 4 Department of Finance, Fintech Center, and Big Data Research Center, Asia University, \\ Taichung City 41354, Taiwan \\ 5 Department of Medical Research, China Medical University, Taichung City 40402, Taiwan \\ 6 Department of Economics and Finance, The Hang Seng University of Hong Kong, Hong Kong 999077, China \\ * Correspondence: wong@asia.edu.tw
}

Received: 5 August 2020; Accepted: 27 September 2020; Published: 16 October 2020

check for updates

\begin{abstract}
This study investigates whether the merger of NASDAQ and OMX could reduce the portfolio diversification possibilities for stock market investors and whether it is necessary to implement national policies and international treaties for the sustainable development of financial markets. Our study is very important because some players in the stock markets have not yet realized that stock exchanges, during the last decades, have moved from government-owned or mutually-owned organizations to private companies, and, with several mergers having occurred, the market is tending gradually to behave like a monopoly. From our analysis, we conclude that increased volatility and reduced diversification opportunities are the results of an increase in the long-run comovement between each pair of indices in Nordic and Baltic stock markets (Denmark, Sweden, Finland, Estonia, Latvia, and Lithuania) and NASDAQ after the merger. We also find that the merger tends to improve the error-correction mechanism for NASDAQ so that it Granger-causes OMX, but OMX loses predictive power on NASDAQ after the merger. We conclude that the merger of NASDAQ and OMX reduces the diversification possibilities for stock market investors and our findings provide evidence to support the argument that it is important to implement national policies and international treaties for the sustainable development of financial markets.
\end{abstract}

Keywords: Stock exchange mergers; cointegration; Nordic and Baltic stock exchanges

\section{Introduction}

The ongoing globalization process and the rapid technological advancements in telecommunications and the internet have increased competition in many, if not most, sectors around the world. To grow or even survive, some companies have used alliances and mergers to expand their activity to other countries. The same is also happening to stock exchanges. Over the last decade, the largest stock exchanges began to merge with other stock exchanges around the world. Some examples include the Euronext (2005), the NYSE acquisition of Euronext (2006), the OMX merger (2003-2006), the merger between the London Stock Exchange and Borsa Italian (2007), and the NASDAQ acquisition of the OMX Nordic stock exchange (2007). These improvements, in terms of new technologies and the possibility of remote access, create a favorable environment to invest in foreign markets, diversify portfolios, attract new investors, and increase trading volumes [1-3]. 
It is important to say that stock exchanges were created like mutual organizations (owned by its member stockbrokers), but some players in the markets still do not realize that major stock exchanges have demutualized; their members sell their shares in an initial public offering, and, actually, they run the business like a normal private company, trying to increase as much as possible the wealth of the shareholders. Examples of some of these movements to private companies are the Australian Securities Exchange (1998), the merger of Euronext with the New York Stock Exchange and NASDAQ (2002), Bursa Malaysia (2004), the New York Stock Exchange (2005), Bolsas y Mercados Españoles and the São Paulo Stock Exchange (2007), and so on. The principal question is, after a stock exchange merger, working like a private company and not like a mutual organization, do the stock exchanges care about the sustainable development of investments, allowing investors to diversify their investments and reduce the risk of their investments? Is it necessary to develop national policies and international treaties for sustainable development and implement and monitor policies for the sustainable development of stock markets?

A recent study, Otchere and Abukari [4], investigated whether the stock exchange mergers are the way for some powerful stock exchanges to become even more powerful in order to get a higher market share of stock exchanges around the world, and they concluded that the industry's concentration does not change the exchanges' profitability during the postmerger period. Unfortunately, Otchere and Abukari [4] do not analyze who the shareholders of the stock exchanges were, and, most importantly, what dividends they received after the merger. Profits cannot increase, but dividend payouts increase. They only analyzed the Herfindahl-Hirschman Index (HHI), "one of the most widely used measures of market concentration".

Prior studies have described that stock exchange mergers increase competition between stock exchanges around the world [5] and decrease the trading costs based on economies of scale [6-9]. Amihud and Mendelson [10], Brennan and Subrahmanyam [11], and Datar et al. [12] also argued that stock exchange consolidations help the listed firms to reduce their cost of equity financing by improving their stock liquidity, informational environment, and governance on the secondary market. Hasan, Schmiedel, and Song [13] provided evidence to show that global exchange merger activities may promote the efficiency of cross-border capital flows and increased governance standards, and thus, it has the potential to benefit both the markets and investors around the world.

Although stock exchange mergers benefit the shareholders of the stock exchanges, they do not generally help individual investors who prefer to diversify their portfolios to reduce risk. In this regard, the motivation of this study is to investigate whether stock exchange mergers can reduce the possibility of investors diversifying their portfolios and reducing risk and whether it is necessary to implement national policies and international treaties for the sustainable development of financial markets. In addition, authors like Rua and Nunes [14] argued that the evaluation of the comovements between stock markets is extremely important for investors to assess the risk of portfolios. Thus, the findings in our analysis are also useful to policymakers because both shocks and crises can be quickly transmitted across closely linked markets [15]. Like in all types of business, having only a very small number of stock exchanges around the world controlling all investments could be dangerous. For example, the EU refused to allow, in 2017, the merger of the German and British stock exchanges, arguing that this would lead to a monopoly.

The first contribution of our study to the literature is that we find that the effect of stock exchange mergers affect the comovement between market indices. In addition, employing cointegration analysis, we find that the comovement between each pair of indices in the Nordic and Baltic stock markets and NASDAQ increases due to the merger. We recognize that the period of the merger concurs with some huge events, e.g., the subprime crises of 2007 and the sovereign crisis. Moreover, it might be the crisis that accelerated the process of the merger. Moreover, using Granger causality tests, we show that the merger tends to improve the error-correction mechanism for NASDAQ so that it Granger-causes OMX, but OMX loses predictive power on NASDAQ after the merger. Despite stock exchange mergers being an "old-fashion story", the strangest situation is that nobody investigated the impact of these 
mergers for investors. Thus, our paper bridges the gap in the literature to investigate the impact of the mergers for investors. In addition, stock exchanges are now (and not in the past!) normal private companies with several shareholders who want benefits and dividends. Thus, another contribution of our paper is that it bridges the gap in the literature to investigate the impact of these mergers by treating stock exchanges as normal private companies with several shareholders that want benefits and dividends. Our findings by using mean-variance (MV) and Omega ratios show that the merger does not reduce returns, yet it increases volatility by reducing diversification. Another important problem is that we move forward (without any investigation from academia before) to a monopoly in terms of stock exchanges around the world. This is our third contribution to make an urgent academic start to analyze stock exchange mergers around the world. The empirical $\backslash$ theoretical contribution of this investigation is to provide evidence to show that because stock exchanges are now running like private companies and the biggest stock exchanges are merging around the world, the diversification possibilities of stock market investors are reducing, and it will be important to implement national policies and international treaties for the sustainable development of financial markets.

Our investigation wants to inform the academics and practitioners about the necessity to further explore, in several areas of finance, the impact of stock exchange mergers. The academics from finance have already made an amazing investigation on boards of directors, governance, and ethics, in several aspects, but it is very strange why the number of researchers that investigate stock exchange mergers is so small. What we know is extremely incipient. It is good to have more investigations into stock exchange mergers from different angles.

Section 2 will describe the literature review and research hypotheses. Section 3 discusses data and all the methodologies being used in our study. Section 4 describes the empirical analysis, and Section 5 concludes.

\section{Literature Review and Research Hypotheses}

\subsection{Literature Review}

Essentially, during the last 20 years, stock exchanges have moved from being government-owned or mutually-owned organizations to being private companies, and it seems that academics are forgetting to analyze the impact of the changes from several aspects of finance and sustainability. Stock exchanges are now performing like normal companies, and they are owned by private shareholders. Despite being private companies, these private stock exchanges decide the listing and compliance standards for companies that want to go public.

If we examine the ownership structure of several other major exchanges, we understand that NYSE Euronext is the largest stock exchange in terms of both market capitalization and traded value; it went public in 2006 and acquired Euronext in 2007. The Nasdaq OMX Group is the second-largest public stock exchange in the world in terms of traded value, and, in 2008, it acquired seven Nordic and Baltic exchanges. Tokyo Stock Exchange is the third-largest private stock exchange in the world. London Stock Exchange, which is owned by the London Stock Exchange Group, is also actually a publicly traded company.

Based on this information, it is possible to conclude that running a stock exchange can be a good business for entrepreneurs. They can then manage the stock exchanges and demand that the companies and investors pay listing and transaction fees, respectively, and traders pay to have access to the markets. Hence, it is not surprising that big stock exchanges try to buy other small stock exchanges in order to control all the fees around the world. Authors like Otchere and Abukari [4] recently examined whether stock exchange mergers could increase efficiency or if it is a question of market power and found that the industry's concentration levels have not significantly increased and the concentration levels do not influence the exchanges' profitability in the postmerger period.

Although the merger of stock exchanges could affect the shareholders of the stock exchanges, it does not generally help individual investors who usually want to diversify their portfolios to reduce 
risk. International portfolio diversification was established in the 1960s and 1970s when the USA and other investors became very active in foreign securities markets [16]. Grubel [17] found that investors gain from internationally diversified portfolios. Since then, this topic has received considerable attention in international finance. International diversification can be beneficial if it reduces the total portfolio risk by adding securities based in different countries, with lower correlations.

Due to the introduction of new technologies and financial market liberalization in recent years, it is becoming easier to invest internationally [16]. The literature, however, has not yet shed much light on whether stock exchange mergers have had any impact on this process. Up to now, economic agents and policymakers have only explored whether national markets have become more integrated and what the impact on international portfolio diversification is. This paper, which considers the merger of NASDAQ with OMX, represents the first step to investigating the effect of mergers on international portfolio diversification.

According to Choudhry et al. [18], Kearney and Lucey [19], and Chen et al. [20], cointegrated stock markets weaken the benefits of international portfolio diversification in the long run. Cointegrated assets exhibit significant long-term comovements, thereby lessening their diversification potential. Authors like Brooks and Del Negro [21,22], King et al. [23], Longin and Solnik [24,25], Lin et al. [26], Karolyi and Stulz [27], and Forbes and Rigobon [28] documented that the comovement of stock returns is not constant across the time. Candelon et al. [29] complemented this information, arguing that comovement analysis should also take into account the distinction between the short- and long-term investors because investors who invest for the short term are naturally more interested in the comovement of stock returns at higher frequencies (short-term fluctuations) whereas long-term investors focus essentially on the relationship at lower frequencies (long-term fluctuations). A'Hearn and Woitek [30] and Pakko [31] also show that the frequency level is important when analyzing comovement. However, besides Smith [32], few investigations make this distinction. Hassan and Naka [33] argue that portfolio diversification benefits would continue to accrue in the short run but not in the long run if markets are cointegrated and that the benefits of international diversification might be overstated for investors with long-term investment horizons.

Charles et al. [34] analyzed the impact of stock exchange mergers on the degree of informational efficiency and found that higher levels of efficiency are less frequent than lower levels of efficiency after a stock exchange merger and that the impact on the levels of efficiency is correlated with the levels of development, size, and both geographical and industrial diversification of the stock exchange.

\subsection{Research Hypotheses}

Our study contributes to the literature on international stock market cointegration by examining the impact of the merger of OMX (Denmark, Sweden, Finland, Estonia, Latvia, and Lithuania; we do not report the result for Norway because we cannot find data for the Norwegian stock market) with NASDAQ. The main hypotheses tested in this paper are

Hypothesis 1 (H1). The comovements between the merged stock indices increase after the merger; and

Hypothesis 2 (H2). Mergers reduce diversification opportunities.

Based on the information that we have already described in Section 2.1—stock exchanges are merging and turning slowly to a monopoly-we conjecture that comovements will increase between the indices and diversification opportunities will be reduced, as stated in Hypotheses 1 and 2 above.

\section{Data and Methodology}

In this section, we discuss the data and methodology being used in our paper. First, we collected data from DataStream. Second, cointegration tests were used to test the long-term relationships between OMX indices and the NASDAQ index. Third, causality tests were utilized to test the linear causal 
relationship between OMX indices and the NASDAQ index. Fourth, we tested whether nonlinear causalities exist between OMX indices and the NASDAQ index. Last, we compared the mean and variance of the returns of the OMX indices and the NASDAQ index before the merger to the ones after the merger.

\subsection{Data}

The data used in this study are the daily NASDAQ index and the six Euronext OMX indices, including Copenhagen 20 Index (Cop), Helsinki 25 Index (Hel), Riga All-Share Gross Index (Riga), Stockholm 30 Index (Sto), Vilnius All-Share Gross Index (Vil), and Tallinn All-Share Gross Index (Tal). Data were extracted from DataStream, and the total return index (capital gains and dividends) is used after the conversion of all currencies to USD (code "X(RI) U $\$$ ").

NASDAQ announced the purchase of OMX, the Swedish-Finnish financial company that controls seven Nordic and Baltic stock exchanges, on 25 May 2007. As of 27 February 2008, the deal was completed. In order to study the effect of the merger in the short, medium, and long run, we used the data from around five years before the merger (1 March 2002) until around five years after the merger (28 February 2013) of the NASDAQ Stock Exchange with OMX on 27 February 2008 and studied the short period (1 year), medium-range period (3 years), and the longer period (5 years) before and after the merger. Among the seven Nordic and Baltic stock exchanges that OMX controls, we do not extend our analysis to the Iceland Stock Exchange since OMX 15 was canceled in 2008 and was replaced by the OMX Iceland 6 index in 2009 due to severe financial problems. In addition, the Armenian Stock Exchange, the eighth stock exchange operated by OMX, is excluded from our sample because it was purchased by OMX after the announcement of the merger studied in this paper.

Figure 1 displays the time-series plots of NASDAQ and the six OMX indices from 1 March 2002 to 28 February 2013. To compare the movements of various indices in one diagram, we adjust each index by dividing the price of each index on 1 March 2002 and multiplied them by 100 so that all indices start from 100. From the figure, we can make several observations. The movement of the six OMX indices and NASDAQ is more homogeneous. The variances of the seven indices become smaller after the merger. All the values of the indices go down from the end of 2007 as a result of the global 2007 financial crisis and recover after the beginning of 2009. Finally, the ascendant trends of the seven indices before the merger are obvious, and the movements after the merger are more random. Thus, from Figure 1, we can conclude that the merger does have some effects on the stock indices. To further explore the relationship, we used a range of different techniques. We describe these techniques in the following subsections.

\subsection{Methodology}

\subsubsection{Cointegration}

Engle and Granger [34] proposed a two-step cointegration test that connects the moving average, autoregressive, and error correction representations for cointegrated systems. Before applying the two-step procedure, we first identify the integrated order of the variables. After confirming that the variables being analyzed are I(1), we applied the following cointegation equation to test whether there is any comovement relationship between any of the OMX indices and the NASDAQ index and whether there is any effect from the merger.

$$
Y_{t}=\delta+\delta_{1} X_{t}+\delta_{2} D_{t}+\delta_{3} X_{t} * D_{t}+\varepsilon_{t}
$$

where

Considering the potential effect of EU accession by Baltic countries in 2004 and the change in reporting regime by listed companies in 2005 (switch to mandatory IFRS reporting by the EU-listed firms, we include dummy variables, year, to control the compound effects. Not every panel includes the variable year since the sample of the panels does not cover 2004 and 2005. 


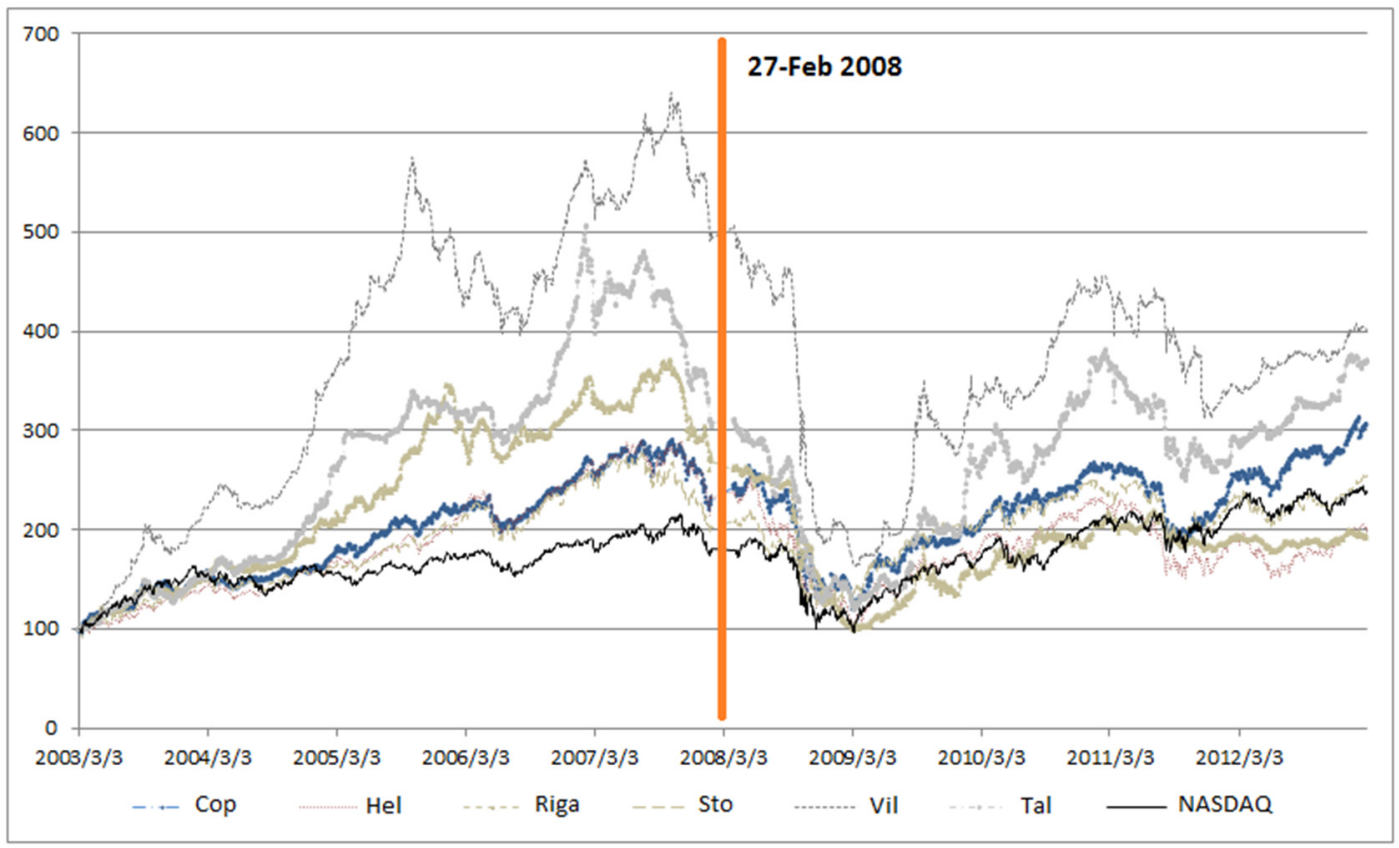

Figure 1. Time-series plots of NASDAQ and the six OMX indices. Note: Cop, Hel, Riga, Sto, Vil, and Tal represent Copenhagen 20 price, Helsinki 25 price, Riga_GI price, Stockholm 30 Index price, Vilnius_GI price, and Tallinn_GI price, respectively. All the price indices equal to spot price divided by the base day price (100), which is on 1 March 2002. The red line denotes the date of the merger of NADSAQ with OMX. Source: author's own calculation.

In addition, we apply the following cointegration equation without the merger dummy variable to test whether there is any comovement relationship between any of the OMX indices and the NASDAQ index in the subperiods separated by the date of the merger.

$$
\mathrm{Y}_{\mathrm{t}}=\delta^{\prime}+\delta_{1}^{\prime} \mathrm{X}_{\mathrm{t}}+\mathrm{u}_{\mathrm{t}}
$$

where $Y_{t}$ and $X_{t}$ are defined in (1). If the standardized residual is not rejected as $I(0)$, then the stock indices $X_{t}$ and $Y_{t}$ are cointegrated in the subperiods separated by the date of the merger.

\subsubsection{Linear Causality}

After establishing the long-run relationship between any of the OMX indices $\left(Y_{t}\right)$ and NASDAQ $\left(X_{t}\right)$, as shown in Equation (2), we proceed to examine the short-run dynamics and test whether there is any causality between any of the OMX indices and the NASDAQ index by using the following short-run dynamic models:

$$
\begin{gathered}
\Delta \mathrm{Y}_{\mathrm{t}}=\delta+\sum_{\mathrm{i}=1}^{\mathrm{n}} \alpha_{\mathrm{i}} \Delta \mathrm{X}_{\mathrm{t}-\mathrm{i}}+\sum_{\mathrm{j}=1}^{\mathrm{m}} \beta_{\mathrm{j}} \Delta \mathrm{Y}_{\mathrm{t}-\mathrm{j}}+\gamma \cdot \mathrm{ECM}_{\mathrm{t}-1}+\mathrm{u}_{1 \mathrm{t}} \\
\Delta \mathrm{X}_{\mathrm{t}}=\delta+\sum_{\mathrm{i}=1}^{\mathrm{n}} \alpha^{\prime}{ }_{\mathrm{i}} \Delta \mathrm{X}_{\mathrm{t}-\mathrm{i}}+\sum_{\mathrm{j}=1}^{\mathrm{m}} \beta^{\prime}{ }_{\mathrm{j}} \Delta \mathrm{Y}_{\mathrm{t}-\mathrm{j}}+\gamma^{\prime} \cdot \mathrm{ECM}_{\mathrm{t}-1}+\mathrm{u}_{2 \mathrm{t}}
\end{gathered}
$$

where $Y_{t}$ and $X_{t}$ are defined in (1), the error correction term $E C M_{t-1}$ is the standard residual at time $t-1$, obtained by running Equation (2), and the speeds of adjustment $\gamma$ and $\gamma^{\prime}$ are the coefficients of $\mathrm{ECM}_{\mathrm{t}-1}$. Engle and Granger [35] proved that when $\mathrm{Y}_{\mathrm{t}}$ and $\mathrm{X}_{\mathrm{t}}$ are cointegrated, there always exists a corresponding error-correction representation, as shown in Equations (3) and (4), implying that the change in the dependent variable is a function of the level of disequilibrium in the cointegration 
relationship captured by the error correction term as well as changes in other explanatory variable(s). The error correction term refers to the level of disequilibrium in the long run relation, while the speeds of adjustment represent the proportion by which the long-run disequilibrium (or imbalance) in the dependent variable is being corrected in each time period. If we do not reject the hypothesis that all $\alpha_{i}=0$ and $\gamma=0$, then $X_{t}$ does not Granger-cause $Y_{t}$. Similarly, the failure to reject that all $\beta^{\prime}{ }_{j}=0$ and $\gamma^{\prime}=0$ suggests that $Y_{t}$ does not Granger-cause $X_{t}$. We note that if any of the OMX indices $\left(Y_{t}\right)$ and NASDAQ $\left(X_{t}\right)$ are not cointegrated (that is, there is no long-run relationship between the OMX indices and NASDAQ) but both $Y_{t}$ and $X_{t}$ are still $I(1)$, then we still apply Equations (3) and (4) to examine whether there is any linear causality between $Y_{t}$ and $X_{t}$ but the error correction term $E C M_{t-1}$ has to be removed from the equations. We note that the causality tests developed by Engle and Granger [35] and Granger [36] are powerful. That is why many recent studies, for example, Billio et al. [37] and Jin \& Kim [38], still apply the tests in their analyses.

\subsubsection{Nonlinear Causality}

Besides classical linear causality, we test nonlinear causality as well. Granger [36] originally proposed a novel idea to test the causal relationship between two-time series variables. Using two strictly stationary and weakly dependent residual series, $\hat{\mathrm{u}}_{1 \mathrm{t}}, \hat{\mathrm{u}}_{2 \mathrm{t}}$, which are obtained from Equations (3) and (4) and are denoted by $x_{t}$ and $y_{t}$, we can detect the nonlinear causal relation. Following Baek and Brock [39], series $Y_{t}$ does not strictly Granger-cause another series $X_{t}$ if and only if:

$$
\operatorname{Pr}\left(\left\|x_{t}^{m}-x_{s}^{m}\right\|<e \mid\left\|x_{t-L x}^{L x}-x_{s-L x}^{L x}\right\|<e,\left\|y_{t-L y}^{L y}-y_{s-L y}^{L y}\right\|<e\right)=\operatorname{Pr}\left(\left\|x_{t}^{m}-x_{s}^{m}\right\|<e \mid\left\|x_{t-L x}^{L x}-x_{s-L x}^{L x}\right\|<e\right)
$$

where $\operatorname{Pr}\left(\right.$ ) denotes probability distribution and \|\| denotes the maximum norm. $\mathrm{m} \geq 1, \mathrm{~L}_{\mathrm{x}}, \mathrm{L}_{\mathrm{y}}>1$ are the given values and $\mathrm{e}>0$.

$x_{t}^{m}$ is the m-length lead vector of $x_{i t}$ :

$$
x_{t}^{m} \equiv\left(x_{t}, x_{t+1}, \ldots, x_{t+m-1}\right), m=1,2, \ldots, t=1,2, \ldots
$$

$x_{t-L x}^{L x}$ refers to the Lx-length lag vector of $x_{i t}$ :

$\mathrm{x}_{\mathrm{t}-\mathrm{L}_{\mathrm{x}}}^{\mathrm{L}_{\mathrm{x}}} \equiv\left(\mathrm{x}_{\mathrm{t}-\mathrm{L}_{\mathrm{x}}}, \mathrm{x}_{\mathrm{t}-\mathrm{L}_{\mathrm{x}}+1}, \ldots, \mathrm{x}_{\mathrm{t}-1}\right), \mathrm{L}_{\mathrm{x}}=1,2, \ldots, \mathrm{t}=\mathrm{L}_{\mathrm{x}}+1, \mathrm{~L}_{\mathrm{x}}+2, \ldots$ and $\mathrm{y}_{\mathrm{t}-\mathrm{Ly}}^{\mathrm{Ly}}$ refers to the Ly-length lag vector of $\mathrm{y}_{\mathrm{t}}$ :

$$
\mathrm{y}_{\mathrm{t}-\mathrm{L}_{\mathrm{y}}}^{\mathrm{L}_{\mathrm{y}}} \equiv\left(\mathrm{y}_{\mathrm{t}-\mathrm{L}_{\mathrm{y}}}, \mathrm{y}_{\mathrm{t}-\mathrm{L}_{\mathrm{y}}+1}, \ldots, \mathrm{y}_{\mathrm{t}-1}\right), \mathrm{L}_{\mathrm{y}}=1,2, \ldots, \mathrm{t}=\mathrm{L}_{\mathrm{y}}+1, \mathrm{~L}_{\mathrm{y}}+2, \ldots
$$

Let $C 1\left(m_{x}+L_{x}, L_{y}, e, n\right) / C 2\left(L_{x}, L_{y}, e, n\right)$ and $C 3\left(m_{x}+L_{x}, e, n\right) / C 4\left(L_{x}, e, n\right)$ denote the ratios of joint probabilities corresponding to the left side and right side of Equation (5). Correlation-integral estimators of the joint probabilities can be written as

$$
\begin{aligned}
& \mathrm{C} 1\left(\mathrm{~m}+\mathrm{L}_{\mathrm{x}}, \mathrm{L}_{\mathrm{y}}, \mathrm{e}, \mathrm{n}\right) \equiv \frac{2}{\mathrm{n}(\mathrm{n}-1)} \sum \sum_{\mathrm{t}<\mathrm{s}} \mathrm{I}\left(\mathrm{x}_{\mathrm{t}-\mathrm{L}_{\mathrm{x}}}^{\mathrm{m}+\mathrm{L}_{\mathrm{x}}}, \mathrm{x}_{\mathrm{s}-\mathrm{L}_{\mathrm{x}}}^{\mathrm{m}+\mathrm{L}_{\mathrm{x}}}, \mathrm{e}\right) \cdot \mathrm{I}\left(\mathrm{y}_{\mathrm{t}-\mathrm{L}_{\mathrm{y}}}^{\mathrm{L}_{\mathrm{y}}}, \mathrm{y}_{\mathrm{s}-\mathrm{L}_{\mathrm{y}}}^{\mathrm{L}_{\mathrm{y}}}, \mathrm{e}\right),
\end{aligned}
$$

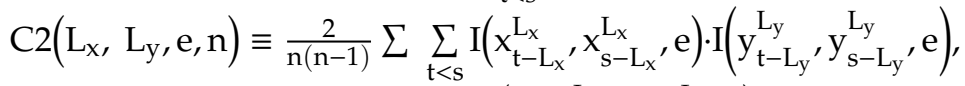

$$
\begin{aligned}
& \mathrm{C} 3\left(\mathrm{~m}+\mathrm{L}_{\mathrm{x}}, \mathrm{e}, \mathrm{n}\right) \equiv \frac{2}{\mathrm{n}(\mathrm{n}-1)} \sum \sum_{\mathrm{t}<\mathrm{s}} \mathrm{I}\left(\mathrm{x}_{\mathrm{t}-\mathrm{L}_{\mathrm{x}}}^{\mathrm{m}+\mathrm{L}_{\mathrm{x}}}, \mathrm{x}_{\mathrm{s}-\mathrm{L}_{\mathrm{x}}}^{\mathrm{m}+\mathrm{L}_{\mathrm{x}}}, \mathrm{e}\right) \text {, } \\
& \mathrm{C} 4\left(\mathrm{~L}_{\mathrm{x}}, \mathrm{e}, \mathrm{n}\right) \equiv \frac{2}{\mathrm{n}(\mathrm{n}-1)} \sum \sum_{\mathrm{t}<\mathrm{s}} \mathrm{I}\left(\mathrm{x}_{\mathrm{t}-\mathrm{L}_{\mathrm{x}}}^{\mathrm{L}_{\mathrm{x}}} \mathrm{x}_{\mathrm{s}-\mathrm{L}_{\mathrm{x}}}^{\mathrm{L}_{\mathrm{x}}} \mathrm{e}\right) \text {, }
\end{aligned}
$$

and

$$
\begin{gathered}
I(x, y, e)=\left\{\begin{array}{l}
0, \text { if }\|x-y\|>e \\
1, \text { if }\|x-y\| \leq e
\end{array}\right. \\
t, s=\max \left(L_{x}, L_{y}\right)+1, \ldots, T-m+1, n=T+1-m-\max \left(L_{x}, L_{y}\right)
\end{gathered}
$$


For the given values of $m, L_{x}, L_{y}$ and $e>0$, under the assumptions that $x_{t}$ and $y_{t}$ are strictly stationary and weakly dependent and satisfy the mixing conditions of Denker and Keller [40], if $y_{t}$ does not strictly Granger-cause $x_{t}$, then the test statistic is

$$
\sqrt{\mathrm{n}}\left(\frac{\mathrm{C} 1\left(\mathrm{~m}+\mathrm{L}_{\mathrm{x}}, \mathrm{L}_{\mathrm{y}}, \mathrm{e}, \mathrm{n}\right)}{\mathrm{C} 2\left(\mathrm{~L}_{\mathrm{x}}, \mathrm{L}_{\mathrm{y}}, \mathrm{e}, \mathrm{n}\right)}-\frac{\mathrm{C} 3\left(\mathrm{~m}+\mathrm{L}_{\mathrm{x}}, \mathrm{e}, \mathrm{n}\right)}{\mathrm{C} 4\left(\mathrm{~L}_{\mathrm{x}}, \mathrm{e}, \mathrm{n}\right)}\right) \sim \mathrm{N}\left(0, \sigma^{2}\left(\mathrm{~m}, \mathrm{~L}_{\mathrm{x}}, \mathrm{L}_{\mathrm{y}}, \mathrm{e}\right)\right)
$$

Readers may refer to Hiemstra and Jones [41], Bai et al. [42-48], and Chow et al. [49] for more information on the test statistic in (7).

\subsubsection{Mean-Variance Analysis and Mean-Omega Analysis}

Traditionally, mean-variance (MV) criteria could be used as tools for decision making. For any two investments with returns $Y_{1}$ and $Y_{2}$ with means $\mu_{1}$ and $\mu_{2}$ and standard deviations $\sigma_{1}$ and $\sigma_{2}$, respectively, $Y_{2}$ is said to dominate $Y_{1}$ for risk averters by the MV criterion if $\mu_{2} \geq \mu_{1}$ and $\sigma_{2} \leq \sigma_{1}$ when at least one inequality holds (Markowitz (1952)). On the other hand, Wong [50] and Guo and Wong [51] define the MV rule for risk seekers such that if $\mu_{2} \geq \mu_{1}$ and $\sigma_{2} \geq \sigma_{1}$, with at least one strict inequality relationship, then $Y_{2}$ is said to dominate $Y_{1}$ by the MV rule of risk seekers.

$\mathrm{MV}$, however, cannot capture all of the risk and reward features of entire return distributions when returns are not normally distributed. The Omega ratio, developed by Keating and Shadwick [52], does not require the normality assumption for the distribution of returns. It measures the likelihood of achieving a given return, such as a minimum acceptable return or a target return. A higher Omega value implies a greater probability that a threshold return will be achieved. It is calculated by creating a ratio between the cumulative return probability of being above and being below the threshold return, representing the probability-weighted ratio of gains versus losses for some targeted return. The Omega ratio is defined as follows:

$$
\Omega(r)=\frac{\int_{r}^{\infty}(1-F(x)) d x}{\int_{-\infty}^{r} F(x) d x}
$$

where $r$ is the threshold return and $\mathrm{F}$ is the cumulative density function of returns.

Since the Omega ratio is the ratio between the expected return in excess of the threshold and the first-order lower partial moment, it is also a risk measure using the first-order lower-partial moment. Compared to MV, the Omega ratio considers all moments and is consistent with stochastic dominance $[46,53]$. We employ it as a measure to compare portfolios before and after the merger. Readers may refer to the following authors for more information: Chow et al [54] on the Omega ratio and stochastic dominance; Chan et al. [55] for the relationship between stochastic dominance and the extension of the mean-variance rule; Ma and Wong [56] Niu, Wong, and Xu [57], Guo, Niu, and Wong [58], and others for the relationship between stochastic dominance and other risk measures.

\section{Empirical Analysis}

Before analyzing the relationship between any of the six OMX indices and the NASDAQ index, we first examined the nature of the indices and exhibit in Table 1 (Panel A/B/C) some basic statistics of the daily stock prices and returns of the indices. The indices include the NASDAQ and the six OMX indices for the periods of one/three/five years (reported in $\mathrm{A} / \mathrm{B} / \mathrm{C}$ panel) before and after the merger of OMX with NASDAQ on 27 February 2008. For easy comparison, we also report the statistics for the combined periods (combining the periods before and after the merger). From the table, we find that except for Tal and NASDAQ in Panel B, the means of all the stock returns studied in this paper are higher before the merger than after the merger in all panels. We also find that the standard deviations of the stock returns of all the indices studied in this paper are smaller before the merger than after the merger in all three panels. The highest values of all indices appear before the merger except for Cop and NASDAQ in Panel C. However, the greatest returns of each index appear after the merger. On the 
other hand, the minimum prices of each index appear after the merger for Panels A and B. For Panel C, the minimum prices of Cop, Hel, Sto, Vil, and Tal indices appear before the merger and those of Riga and NASDAQ indices appear after the merger.

Table 1. Descriptive statistics of the price index and return of the stock index.

\begin{tabular}{|c|c|c|c|c|c|c|c|c|c|c|}
\hline \multicolumn{11}{|c|}{ Panel A: One Year Before and/or After Stock Exchange Merger } \\
\hline & \multirow[t]{2}{*}{ Variable } & \multirow[t]{2}{*}{$\mathbf{N}$} & \multicolumn{2}{|c|}{ Mean } & \multicolumn{2}{|c|}{ Min } & \multicolumn{2}{|c|}{ Max } & \multicolumn{2}{|c|}{ Std.Dev } \\
\hline & & & Price & Return & Price & Return & Price & Return & Price & Return \\
\hline \multirow[t]{7}{*}{ Combined } & Cop & 419 & 415.087 & -0.163 & 233.945 & -11.721 & 517.671 & 10.586 & 86.473 & 2.182 \\
\hline & Hel & 419 & 2603.797 & -0.204 & 1254.775 & -8.906 & 3379.03 & 9.286 & 651.039 & 2.153 \\
\hline & Riga & 419 & 547.645 & -0.262 & 210.556 & -9.738 & 764.497 & 9.157 & 161.806 & 1.766 \\
\hline & Sto & 419 & 988.065 & -0.142 & 567.613 & -7.512 & 1311.872 & 11.066 & 228.714 & 2.244 \\
\hline & Vil & 419 & 423.762 & -0.27 & 161.268 & -9.111 & 591.436 & 11.001 & 129.826 & 1.759 \\
\hline & Tal & 419 & 656.521 & -0.277 & 260.189 & -7.046 & 991.611 & 7.603 & 233.178 & 1.64 \\
\hline & NASDAQ & 419 & 2291.399 & -0.123 & 1316.12 & -9.588 & 2859.12 & 11.159 & 417.943 & 2.242 \\
\hline \multirow[t]{7}{*}{ Before } & Cop & 210 & 478.490 & -0.053 & 391.124 & -6.699 & 517.671 & 3.744 & 26.350 & 1.336 \\
\hline & Hel & 210 & 3129.462 & -0.048 & 2503.433 & -4.797 & 3379.030 & 6.916 & 169.782 & 1.419 \\
\hline & Riga & 210 & 681.379 & -0.094 & 535.159 & -9.738 & 764.497 & 4.386 & 52.839 & 1.285 \\
\hline & Sto & 210 & 1182.711 & -0.095 & 921.284 & -4.133 & 1311.872 & 3.965 & 91.379 & 1.446 \\
\hline & Vil & 210 & 524.096 & -0.035 & 452.761 & -6.533 & 591.436 & 3.144 & 34.037 & 1.083 \\
\hline & Tal & 210 & 860.223 & -0.141 & 627.225 & -6.112 & 991.611 & 3.134 & 89.380 & 1.166 \\
\hline & NASDAQ & 210 & 2582.087 & -0.005 & 2292.270 & -3.839 & 2859.120 & 3.406 & 121.941 & 1.249 \\
\hline \multirow[t]{7}{*}{ After } & Cop & 209 & 351.381 & -0.274 & 233.945 & -11.721 & 468.661 & 10.586 & 78.694 & 2.783 \\
\hline & Hel & 209 & 2075.618 & -0.360 & 1254.775 & -8.906 & 2939.774 & 9.286 & 513.341 & 2.692 \\
\hline & Riga & 209 & 413.271 & -0.431 & 210.556 & -7.859 & 543.192 & 9.157 & 116.655 & 2.134 \\
\hline & Sto & 209 & 792.487 & -0.190 & 567.613 & -7.512 & 1036.856 & 11.066 & 141.588 & 2.831 \\
\hline & Vil & 209 & 322.949 & -0.507 & 161.268 & -9.111 & 468.460 & 11.001 & 111.049 & 2.219 \\
\hline & Tal & 209 & 451.845 & -0.413 & 260.189 & -7.046 & 641.255 & 7.603 & 131.347 & 2.001 \\
\hline & NASDAQ & 209 & 1999.320 & -0.241 & 1316.120 & -9.588 & 2533.730 & 11.159 & 406.275 & 2.916 \\
\hline \multicolumn{11}{|c|}{ Panel B: Three Years Before and/or After Stock Exchange Merger } \\
\hline & Variable & $\mathbf{N}$ & \multicolumn{2}{|c|}{ Mean } & \multicolumn{2}{|c|}{ Min } & \multicolumn{2}{|c|}{ Max } & \multicolumn{2}{|c|}{ Std.Dev } \\
\hline & & & Price & Return & Price & Return & Price & Return & Price & Return \\
\hline Combined & Cop & 1336 & 386.488 & 0.028 & 213.113 & -11.721 & 517.671 & 10.586 & 68.585 & 1.59 \\
\hline & Hel & 1336 & 2354.08 & 0.021 & 1189.091 & -8.906 & 3379.03 & 9.286 & 512.892 & 1.657 \\
\hline & Riga & 1336 & 483.633 & 0.008 & 203.157 & -9.738 & 764.497 & 10.18 & 157.433 & 1.591 \\
\hline & Sto & 1336 & 969.304 & 0.028 & 567.613 & -7.512 & 1311.872 & 11.066 & 166.667 & 1.657 \\
\hline & Vil & 1336 & 381.602 & 0.013 & 149.964 & -9.111 & 591.436 & 11.001 & 110.116 & 1.435 \\
\hline & Tal & 1336 & 609.36 & 0.025 & 244.991 & -7.046 & 1043.29 & 12.095 & 185.545 & 1.404 \\
\hline & NASDAQ & 1336 & 2232.037 & 0.026 & 1268.64 & -9.588 & 2859.12 & 11.159 & 316.366 & 1.606 \\
\hline Before & Cop & 668 & 412.257 & 0.040 & 306.250 & -6.699 & 517.671 & 3.744 & 57.410 & 1.090 \\
\hline & Hel & 668 & 2635.243 & 0.048 & 1852.999 & -4.797 & 3379.030 & 6.916 & 439.977 & 1.154 \\
\hline & Riga & 668 & 613.890 & 0.041 & 422.915 & -9.738 & 764.497 & 4.929 & 83.356 & 1.121 \\
\hline & Sto & 668 & 1027.044 & 0.031 & 748.240 & -4.882 & 1311.872 & 5.349 & 154.577 & 1.205 \\
\hline & Vil & 668 & 459.814 & 0.046 & 335.853 & -6.533 & 591.436 & 4.216 & 61.528 & 1.051 \\
\hline & Tal & 668 & 735.038 & 0.024 & 534.855 & -6.112 & 1043.290 & 5.569 & 127.185 & 0.959 \\
\hline & NASDAQ & 668 & 2329.348 & 0.023 & 1904.180 & -3.936 & 2859.120 & 4.366 & 220.080 & 1.027 \\
\hline After & Cop & 668 & 360.718 & 0.015 & 213.113 & -11.721 & 475.021 & 10.586 & 69.200 & 1.968 \\
\hline & Hel & 668 & 2072.916 & -0.005 & 1189.091 & -8.906 & 2939.774 & 9.286 & 417.837 & 2.040 \\
\hline & Riga & 668 & 353.377 & -0.025 & 203.157 & -7.859 & 543.192 & 10.180 & 93.140 & 1.952 \\
\hline & Sto & 668 & 911.565 & 0.025 & 567.613 & -7.512 & 1179.295 & 11.066 & 158.194 & 2.011 \\
\hline & Vil & 668 & 303.391 & -0.019 & 149.964 & -9.111 & 468.460 & 11.001 & 90.727 & 1.736 \\
\hline & Tal & 668 & 483.683 & 0.026 & 244.991 & -7.046 & 786.422 & 12.095 & 145.233 & 1.740 \\
\hline & NASDAQ & 668 & 2134.725 & 0.030 & 1268.640 & -9.588 & 2833.950 & 11.159 & 364.584 & 2.027 \\
\hline & & Pan & C: Five Yea & Before & nd After S & Exchar & e Merger & & & \\
\hline & Variable & $\mathbf{N}$ & Me & & & & & & & Dev \\
\hline & & & Price & Return & Price & Return & Price & Return & Price & Return \\
\hline Combined & Cop & 2273 & 370.602 & 0.047 & 169.04 & -11.72 & 556.876 & 10.586 & 87.817 & 1.417 \\
\hline & Hel & 2273 & 2141.021 & 0.031 & 1100.381 & -8.906 & 3379.03 & 9.286 & 525.714 & 1.579 \\
\hline & Riga & 2273 & 429.502 & 0.032 & 203.157 & -9.738 & 764.497 & 10.18 & 142.039 & 1.351 \\
\hline & Sto & 2273 & 918.075 & 0.041 & 432.36 & -7.512 & 1311.872 & 11.066 & 200.033 & 1.546 \\
\hline & Vil & 2273 & 336.379 & 0.06 & 92.385 & -11.94 & 591.436 & 11.001 & 115.546 & 1.289 \\
\hline & Tal & 2273 & 556.602 & 0.057 & 204.11 & -7.046 & 1043.29 & 12.095 & 191.942 & 1.29 \\
\hline & NASDAQ & 2273 & 2284.257 & 0.04 & 1268.64 & -9.588 & 3213.59 & 11.159 & 423.65 & 1.484 \\
\hline
\end{tabular}


Table 1. Cont.

\begin{tabular}{ccccccccccc}
\hline \multicolumn{7}{c}{ Panel C: Five Years Before and After Stock Exchange Merger } \\
\hline & Variable & N & \multicolumn{2}{c}{ Mean } & \multicolumn{2}{c}{ Min } & \multicolumn{2}{c}{ Max } & Std.Dev \\
\hline \multirow{2}{*}{ Before } & & & Price & Return & Price & Return & Price & Return & Price & Return \\
& Cop & 1141 & 346.173 & 0.073 & 169.040 & -6.699 & 517.671 & 3.744 & 92.067 & 1.031 \\
& Hel & 1141 & 2181.587 & 0.074 & 1100.381 & -4.797 & 3379.030 & 6.916 & 649.357 & 1.090 \\
& Riga & 1141 & 488.304 & 0.087 & 203.730 & -9.738 & 764.497 & 4.967 & 166.237 & 1.034 \\
& Sto & 1141 & 867.496 & 0.062 & 432.360 & -4.882 & 1311.872 & 5.349 & 229.725 & 1.186 \\
& Vil & 1141 & 350.069 & 0.140 & 92.385 & -6.533 & 591.436 & 4.536 & 143.311 & 1.016 \\
& Tal & 1141 & 563.974 & 0.099 & 204.110 & -6.112 & 1043.290 & 7.179 & 230.223 & 0.979 \\
& NASDAQ & 1141 & 2140.534 & 0.051 & 1278.370 & -3.936 & 2859.120 & 4.698 & 311.455 & 1.113 \\
\hline After & Cop & 1132 & 395.226 & 0.022 & 213.113 & -11.72 & 556.876 & 10.586 & 75.757 & 1.720 \\
& Hel & 1132 & 2100.132 & -0.012 & 1189.091 & -8.906 & 2939.774 & 9.286 & 356.147 & 1.951 \\
& Riga & 1132 & 370.232 & -0.024 & 203.157 & -7.859 & 543.192 & 10.180 & 75.298 & 1.606 \\
& Sto & 1132 & 969.056 & 0.020 & 567.613 & -7.512 & 1205.099 & 11.066 & 148.338 & 1.839 \\
& Vil & 1132 & 322.579 & -0.021 & 149.964 & -11.94 & 468.460 & 11.001 & 75.754 & 1.512 \\
& Tal & 1132 & 549.172 & 0.016 & 244.991 & -7.046 & 786.422 & 12.095 & 143.088 & 1.540 \\
& NASDAQ & 1132 & 2429.122 & 0.029 & 1268.640 & -9.588 & 3213.590 & 11.159 & 470.027 & 1.781 \\
\hline
\end{tabular}

Note: Data was extracted from DataStream. Cop, Hel, Riga, Sto, Vil, and Tal represent Copenhagen 20 price,

Helsinki 25 price, Riga_GI price, Stockholm 30 index price, Vilnius_GI price, and Tallinn_GI price, respectively.

Source: author's own calculation, using Eviews software.

\subsection{Cointegration}

Before applying the cointegration tests, we first employed the Philips-Perron (PP) unit-root test to examine the stationarity property of the variables for the periods of $1 / 3 / 5$ years before and after the merger of OMX with NASDAQ, exclusively and inclusively. We report in Table 2 the stationarity status for each series on both level and first differences. The table shows that all the price series involved do not reject the null hypothesis that the series has a unit root at the $10 \%$ level but reject the null hypothesis at the $1 \%$ significant level after the first difference, implying that all the indices are I(1) in the subperiods before and after the merger and in the entire combined period. This meets the nonstationarity requirement for the establishment of the cointegration relationship.

Table 2. Unit-root tests for the levels and differences of stock price series.

\begin{tabular}{cccccccc}
\hline & \multicolumn{2}{c}{ 1 Year } & \multicolumn{2}{c}{ 3 Year } & \multicolumn{2}{c}{5 Year } \\
\hline Period & Series & Level & Difference & Level & Difference & Level & Difference \\
\hline Combined & Cop & 0.4441 & $0.0000^{* * *}$ & 0.8336 & $0.0000^{* * *}$ & 0.6700 & $0.0000^{* * *}$ \\
& Hel & 0.3379 & $0.0000^{* * *}$ & 0.8423 & $0.0000^{* * *}$ & 0.7536 & $0.0000^{* * *}$ \\
& Riga & 0.8161 & $0.0000^{* * *}$ & 0.7443 & $0.0000^{* * *}$ & 0.7240 & $0.0000^{* * *}$ \\
& Sto & 0.1117 & $0.0000^{* * *}$ & 0.8280 & $0.0000^{* * *}$ & 0.5850 & $0.0000^{* * *}$ \\
& Vil & 0.8489 & $0.0000^{* * *}$ & 0.7849 & $0.0000^{* * *}$ & 0.6566 & $0.0000^{* * *}$ \\
& Tal & 0.1743 & $0.0000^{* * *}$ & 0.8936 & $0.0000^{* * *}$ & 0.8278 & $0.0000^{* * *}$ \\
& NASDAQ & 0.7209 & $0.0000^{* * *}$ & 0.8750 & $0.0000^{* * *}$ & 0.4624 & $0.0000^{* * *}$ \\
\hline Before & Cop & 0.8858 & $0.0000^{* * *}$ & 0.8370 & $0.0000^{* * *}$ & 0.7094 & $0.0000^{* * *}$ \\
& Hel & 0.7040 & $0.0000^{* * *}$ & 0.8615 & $0.0000^{* * *}$ & 0.5135 & $0.0000^{* * *}$ \\
& Riga & 0.9930 & $0.0000^{* * *}$ & 0.7863 & $0.0000^{* * *}$ & 0.3295 & $0.0000^{* * *}$ \\
& Sto & 0.5533 & $0.0000^{* * *}$ & 0.7841 & $0.0000^{* * *}$ & 0.7780 & $0.0000^{* * *}$ \\
& Vil & 0.9969 & $0.0000^{* * *}$ & 0.8134 & $0.0000^{* * *}$ & 0.4094 & $0.0000^{* * *}$ \\
& Tal & 0.9385 & $0.0000^{* * *}$ & 0.7034 & $0.0000^{* * *}$ & 0.7734 & $0.0000^{* * *}$ \\
& NASDAQ & 0.8846 & $0.0000^{* * *}$ & 0.7995 & $0.0000^{* * *}$ & 0.7933 & $0.0000^{* * *}$ \\
\hline & Cop & 0.4228 & $0.0000^{* * *}$ & 0.9519 & $0.0000^{* * *}$ & 0.8075 & $0.0000^{* * *}$ \\
& Hel & 0.2001 & $0.0000^{* * *}$ & 0.9588 & $0.0000^{* * *}$ & 0.4073 & $0.0000^{* * *}$ \\
& Riga & 0.5115 & $0.0000^{* * *}$ & 0.9136 & $0.0000^{* * *}$ & 0.2455 & $0.0000^{* * *}$ \\
& Sto & 0.2985 & $0.0000^{* * *}$ & 0.9115 & $0.0000^{* * *}$ & 0.7812 & $0.0000^{* * *}$ \\
& Vil & 0.8570 & $0.0000^{* * *}$ & 0.9416 & $0.0000^{* * *}$ & 0.3187 & $0.0000^{* * *}$ \\
& Tal & 0.7969 & $0.0000^{* * *}$ & 0.8616 & $0.0000^{* * *}$ & 0.7418 & $0.0000^{* * *}$ \\
& NASDAQ & 0.2925 & $0.0000^{* * *}$ & 0.9289 & $0.0000^{* * *}$ & 0.8401 & $0.0000^{* * *}$ \\
\hline
\end{tabular}

This table reports $p$-values of unit-root tests for the level and differences of stock price series. ${ }^{* * *}$ denotes the significance of PP tests at $1 \%$ level. Source: author's own calculation. 
We turn to examine whether there is any cointegration relationship in the first, third, and fifth years, before and after the merger and in the combined periods. We report the results of the cointegration model stated in Equation (1) for the combined periods in Table 3. The compound effects have been controlled as well. From Table 3, we find that the $p$-values of PP tests of the residuals after fitting the cointegration equation stated in (1) are all smaller than $1 \%$. The results imply that there is a cointegrated relationship between all of the six OMX indices and the NASDAQ index. In other words, we can conclude that there is a common stochastic long-term trend between each of the OMX indices and the NASDAQ index over the entire period after the dummy variable of the merger is included.

Table 3. Estimation of cointegration tests using the daily price index of OMX with a dummy variable.

\begin{tabular}{|c|c|c|c|c|c|c|}
\hline & \multicolumn{6}{|c|}{ Cointegration between NASDAQ and OMX } \\
\hline & $\delta$ & $\delta_{1}$ & $\delta_{2}$ & $\delta_{3}$ & f-Test & $\mathbf{P P}$ \\
\hline \multicolumn{7}{|c|}{1 year } \\
\hline Cop & $52.5514 * *$ & $0.1650 * * *$ & $-84.8132^{* * *}$ & $0.0269^{* * *}$ & $41.36^{* * *}$ & $0.0000 * * *$ \\
\hline Hel & $487.9849 * * *$ & $1.0230 * * *$ & $-858.0576^{* * *}$ & $0.2003^{* * *}$ & $224.48^{* * *}$ & $0.0001^{* * *}$ \\
\hline Riga & $111.3546 *$ & $0.2208 * * *$ & $-245.0116^{* * *}$ & $0.0528 * *$ & $201.28^{* * *}$ & $0.0009 * * *$ \\
\hline Sto & $486.7593 * * *$ & $0.2695^{* * *}$ & $-359.9789 * * *$ & 0.0634 & $236.27^{* * *}$ & $0.0073 * * *$ \\
\hline Vil & -9.1745 & $0.2065^{* * *}$ & $-201.9048^{* * *}$ & $0.0606^{* * *}$ & $125.68^{* * *}$ & $0.0000^{* * *}$ \\
\hline Tal & $471.4097^{* * *}$ & $0.1506^{* * *}$ & $-645.3527^{* * *}$ & $0.1624^{* * *}$ & $342.62^{* * *}$ & $0.0043^{* * *}$ \\
\hline \multicolumn{7}{|c|}{3 year } \\
\hline Cop & $-115.0172^{* * *}$ & $0.2284^{* * *}$ & $91.5413^{* * *}$ & $-0.049 * * *$ & $4278.63 * * *$ & $0.0000 * * *$ \\
\hline Hel & $-704.4742^{* * *}$ & $1.4719^{* * *}$ & $524.1054^{* * *}$ & $-0.418^{* * *}$ & $4937.93^{* * *}$ & $0.0000^{* * *}$ \\
\hline Riga & $71.8514^{* *}$ & $0.2392 * * *$ & $-80.2937^{* *}$ & $-0.070 * * *$ & $2102.27^{* * *}$ & $0.0008^{* * *}$ \\
\hline Sto & $-95.5730^{* * *}$ & $0.4948^{* * *}$ & $160.3319^{* * *}$ & $-0.099 * * *$ & $2403.82^{* * *}$ & $0.0004^{* * *}$ \\
\hline Vil & $-242.3399 * * *$ & $0.2953 * * *$ & $89.3141 * * *$ & $-0.082 * * *$ & $2310.10^{* * *}$ & $0.0000^{* * *}$ \\
\hline Tal & $-355.3489^{* * *}$ & $0.4683^{* * *}$ & 38.9749 & $-0.093 * * *$ & $2404.94^{* * *}$ & $0.0000 * * *$ \\
\hline \multicolumn{7}{|c|}{5 year } \\
\hline Cop & $-191.8298^{* * *}$ & $0.2570^{* * *}$ & $221.8092^{* * *}$ & $-0.106^{* * *}$ & $4610.03^{* * *}$ & $0.0000^{* * *}$ \\
\hline Hel & $-1489.181^{* * *}$ & $1.7700 * * *$ & $2495.85^{* * *}$ & $-1.320 * * *$ & $1818.72 * * *$ & $0.0005^{* * *}$ \\
\hline Riga & $-424.1897^{* * *}$ & $0.4347^{* * *}$ & $571.373 * * *$ & $-0.343 * * *$ & $1964.28^{* * *}$ & $0.0002 * * *$ \\
\hline Sto & $-462.3664^{* * *}$ & $0.6365^{* * *}$ & $764.942 * * *$ & $-0.362 * * *$ & $3120.89^{* * *}$ & $0.0001 * * *$ \\
\hline Vil & $-469.9011^{* * *}$ & $0.3834^{* * *}$ & $518.698^{* * *}$ & $-0.271^{* * *}$ & $2086.51^{* * *}$ & $0.0000^{* * *}$ \\
\hline Tal & $-688.0900^{* * *}$ & $0.5953^{* * *}$ & $571.282 * * *$ & $-0.321^{* * *}$ & $2490.92^{* * *}$ & $0.0000^{* * *}$ \\
\hline
\end{tabular}

We exclude the period of 1 February 2008 to 31 March 2008 since the effect of the merger may have begun before or after the date of merger as the result of different expectations of the merger date in different markets. Iceland is excluded as well due to complicated financial problems during the ten analyzed periods. $D_{t}$ is a dummy variable equal to 1 if time is after the merger date. Six OMX indices are regarded as dependent variables, and the NASDAQ index is regarded as an independent variable. Dummy variable year is included to control compound effects. The $p$-values of PP tests are reported in this table. ***, and ${ }^{* * *}$ denote the significance at $10 \%, 5 \%$ and $1 \%$ levels, respectively. Source: author's own calculation. $Y_{t}=\delta+\delta_{1} X_{t}+\delta_{2} D_{t}+\delta_{3} X_{t} * D_{t}+$ year $+\varepsilon_{t}$.

In addition, we find that except for the intercept for Vil in the short-run (one year before and after the merger), which is insignificant, all other estimates of both the intercepts and the slopes are significant for the short, medium, and long runs. Moreover, except for the short-run Vil, which is negative, all other intercepts are positive in the short run. They become negative in the medium run and more negative in the long run. On the other hand, the slope coefficients are all positive, implying that each of the OMX indices and the NASDAQ index are moving in the same direction. In addition, we find that except for the slope for Hel, which is larger in the medium run than in the long run, for all other slopes, the longer the time period being tested, the larger the values become. These findings imply that, in general, the positive relationship between each of the OMX indices and NASDAQ index is stronger in the long run than in the short run.

We then looked into the effects of the control merger dummy $D_{t}$ on the cointegration relationship in Equation (1). To do so, we examined the estimates of both $\delta_{2}$ and $\delta_{3}$. From Table 3, we find that 
all estimates of $\delta_{3}$ except Sto are statistically significant. Briefly, 1-year Riga is significant at the 5\% significant level and all the others at the $1 \%$ level. All estimates of $\delta_{2}$ are statistically significant at the $1 \%$ level except for 3-year Tal. The implication is that the control merger dummy $\mathrm{D}_{\mathrm{t}}$ strongly affects both the intercept and the slope of the cointegration model in (1). The results also imply that the long-run linear relationships between each OMX index and the NASDAQ Index change after the merger, irrespective of the sample time period in question. When we check the signs of the estimates of $\delta_{2}$ and $\delta_{3}$ for different periods, we find the following two interesting results: (1) The estimates of $\delta_{3}$ are all significantly positive in the period one year before the merger to one year after the merger. All become significantly negative in the periods of three and five years before and after the merger. The absolute values of the coefficients are larger for the five-year periods than for the three-year periods. (2) On the other hand, the estimates of $\delta_{2}$ are all significantly negative in the period one year before the merger to one year after the merger. Except for Riga, the estimates of $\delta_{2}$ become significantly positive in the period of three years before the merger to three years after the merger. For the period of five years before and after the merger, the estimates of $\delta_{2}$ are all significantly positive and larger than the three-year before-and-after periods.

The first finding implies that the merger has a positive effect on the comovement of the OMX indices and NASDAQ in the short run (one year before to one year after the merger). In the medium run ( 3 years before and after), the effect is negative and becomes more pronounced in the longer run ( 5 years before and after). The second finding implies that the merger has a negative effect on the OMX indices in the short run. In the medium run, the effect is positive and becomes more pronounced in the longer run. Taken together, the two findings suggest strong short-run diversification effects that are reversed and exacerbated as the sample period increases.

To further investigate the impact of the merger on the integration between the OMX indices and NASDAQ, we estimated the cointegration model stated in Equation (2) on separate samples and report the results in Table 4. Since the conclusion drawn from the results of Table 4 should be similar to those from Table 3, we only report the results that Table 3 cannot reveal.

Table 4. Estimation of the cointegration test using the subperiod daily price index of OMX.

\begin{tabular}{|c|c|c|c|c|c|c|}
\hline & \multicolumn{3}{|c|}{ Before the Merger } & \multicolumn{3}{|c|}{ After the Merger } \\
\hline & $\delta^{\prime}$ & $\delta_{1}^{\prime}$ & PP & $\delta^{\prime}$ & $\delta_{1}^{\prime}$ & PP \\
\hline \multicolumn{7}{|c|}{1 year } \\
\hline Cop & $52.5514^{* *}$ & $0.1650 * * *$ & 0.1487 & $-32.2618^{* * *}$ & $0.1919^{* * *}$ & $0.0000^{* * *}$ \\
\hline Hel & $487.9849^{* * *}$ & $1.0230 * * *$ & 0.1243 & $-370.0727^{* * *}$ & $1.2233^{* * *}$ & $0.0037^{* * *}$ \\
\hline Riga & $111.3546^{*}$ & $0.2208^{* * *}$ & 0.2493 & $-133.6570^{* * *}$ & $0.2736^{* * *}$ & $0.0055^{* * *}$ \\
\hline Sto & $486.7593^{* * *}$ & $0.2695^{* * *}$ & 0.7736 & $126.7804^{* * *}$ & $0.3330^{* * *}$ & $0.0013^{* * *}$ \\
\hline Vil & -9.1745 & $0.2065^{* * *}$ & $0.0110^{* *}$ & $-211.0793^{* * *}$ & $0.2671^{* * *}$ & $0.0000^{* * *}$ \\
\hline Tal & $471.4097^{* * *}$ & $0.1506^{* * *}$ & 0.8402 & $-173.9431^{* * *}$ & $0.3130^{* * *}$ & $0.0002^{* * *}$ \\
\hline \multicolumn{7}{|c|}{3 year } \\
\hline Cop & $-170.2508^{* * *}$ & $0.2501^{* * *}$ & $0.0000^{* * *}$ & $-24.5914^{* * *}$ & $0.1805^{* * *}$ & $0.0010^{* * *}$ \\
\hline Hel & $-1740 * * *$ & $1.8785^{* * *}$ & $0.0024^{* * *}$ & $-212.3361^{* * *}$ & $1.0705^{* * *}$ & $0.0014^{* * *}$ \\
\hline Riga & $-100.5118^{* * *}$ & $0.3067^{* * *}$ & $0.0062^{* * *}$ & -15.8479 & $0.1730^{* * *}$ & $0.0280 * *$ \\
\hline Sto & $-441.8336^{* * *}$ & $0.6306^{* * *}$ & $0.0487^{* *}$ & $55.4960^{* * *}$ & $0.4010^{* * *}$ & $0.0343^{* *}$ \\
\hline Vil & $-72.1086^{* * *}$ & $0.2284^{* * *}$ & $0.0039^{* * *}$ & $-161.5694^{* * *}$ & $0.2178^{* * *}$ & $0.0032^{* * *}$ \\
\hline Tal & $-355.9487^{* * *}$ & $0.4684^{* * *}$ & $0.0497^{* *}$ & $-307.5832^{* * *}$ & $0.3707^{* * *}$ & $0.0005^{* * *}$ \\
\hline \multicolumn{7}{|c|}{5 year } \\
\hline Cop & $-251.2215^{* * *}$ & $0.2791 * * *$ & $0.0010^{* * *}$ & $33.8308^{* * *}$ & $0.1488^{* * *}$ & $0.0087^{* * *}$ \\
\hline Hel & $-2015^{* * *}$ & $1.9608^{* * *}$ & $0.0009^{* * *}$ & $994.3418^{* * *}$ & $0.4552^{* * *}$ & $0.0106^{* *}$ \\
\hline Riga & $-528.6675^{* * *}$ & $0.4751^{* * *}$ & $0.0083^{* * *}$ & $143.3833^{* * *}$ & $0.0934^{* *}$ & $0.0058^{* * *}$ \\
\hline Sto & $-608.9909^{* * *}$ & $0.6898^{* * *}$ & $0.0063^{* * *}$ & $304.4105^{* * *}$ & $0.2736^{* * *}$ & $0.0402 * *$ \\
\hline Vil & $-526.5326^{* * *}$ & $0.4095^{* * *}$ & $0.0088^{* * *}$ & $45.1471^{* * *}$ & $0.1142^{* * *}$ & $0.0051^{* * *}$ \\
\hline Tal & $-839.2157^{* * *}$ & $0.6555^{* * *}$ & $0.0098^{* * *}$ & $-112.1704^{* * *}$ & $0.2723^{* * *}$ & $0.0036^{* * *}$ \\
\hline
\end{tabular}

This table reports the results of cointegration tests using subsamples-one, three, and five years before and after the merger of NASDAQ with OMX. The $p$-values of PP tests are reported in this table. Six OMX indices are regarded as dependent variables and the NASDAQ index is regarded as an independent variable. ${ }^{*},{ }^{* *}$, and ${ }^{* * *}$ denote the significance of tests at $10 \%, 5 \%$, and $1 \%$ levels, respectively. Source: author's own calculation. $\mathrm{Y}_{\mathrm{t}}=\delta^{\prime}+\delta_{1}{ }^{\prime} \mathrm{X}_{\mathrm{t}}+\mathrm{u}_{\mathrm{t}}$. 
The most striking results from Equation (2) that Equation (1) cannot reveal is that except for Vil, none of the OMX indices are cointegrated with NASDAQ in the one-year short-run period before the merger, but all become cointegrated after the merger, implying that the merger of NASDAQ and OMX becomes more sustainable. In the medium/long run, all OMX indices are cointergrated with the NASDAQ index before and after the merger at or above the 5\% significant level.

We turn to examine the impact of the merger on the intercept and slope. We first examined the intercept coefficients $\left(\delta^{\prime}\right)$. We find that with the exception of Vil, the intercepts are all positive, and, with the exception of Sto, all become negative in the short run after the merger. On the other hand, in the median run, the intercepts are all negative before the merger. They remain negative after the merger but with considerably smaller absolute values. All are strongly negative in the long run before the merger and, except for Tal, become strongly positive.

Comparing the coefficients of slopes before the merger in Table 3 with the coefficients of slopes $\left(\delta_{1}{ }^{\prime}\right)$ in Table 4 and the coefficients of slopes $\left(\delta_{1}{ }^{\prime}\right)$ after the merger, all become larger in the short run but become smaller in the median run and become further smaller in the long run. This finding is also consistent with the results that the merger had a positive effect on the comovement of the OMX indices and NASDAQ in the short run but a negative effect on the comovement of the OMX indices and NASDAQ in a median period and a more negative effect in the long run.

In all, we conclude that OMX indices and the NASDAQ index have a positive common trend, and the comovement between them enlarges after the merger in the short run but diminishes in the long run. The OMX Exchange operates eight stock exchanges, mainly in the Nordic and Baltic countries, while NASDAQ is mainly in the USA. Before the merger, OMX and NASDAQ were mainly influenced by their local financial issues in the short run. This could be the reason why these two exchanges were not cointegrated in the short run. Meanwhile, financial markets are linked with each other nowadays, and, then, two long-distance markets may be cointegrated with each other in the long run if affected by a similar global financial environment. However, after the merger, OMX and NASDAQ became one company and were cointegrated even in the short run. Our finding implies that the merger of NASDAQ and OMX becomes more sustainable.

\subsection{Linear Causality}

Since all variables are I(1), and there is cointegration between all OMX indices and the NASDAQ index except at one year before the merger, we next employ an error-correction model (ECM; Engle and Granger, [34]) to test whether there is any unidirectional or bidirectional relationship between the NASDAQ and OMX indices. The main results of the Granger causality test are reported in Tables 5 and 6, including the estimated speeds of adjustment. The null hypothesis of Table 5 is that NASDAQ does not Granger-cause OMX indices, while the null hypothesis of Table 6 is that OMX indices do not Granger-cause the NASDAQ index.

According to Table 5, all the statistics of the F-test are significant at the $1 \%$ level, implying that the NASDAQ index Granger causes the OMX indices both before and after the merger, no matter how long the time period is. When we further assess the effect of the merger and estimate the speeds of adjustment, we find that the estimates of the error correction mechanism $(\gamma)$ for NASDAQ causing OMX (except Vil) are not significant one year before the merger. Five out of seven become significant one year after the merger. Only two of $\gamma$ are significant in the medium run before the merger, but all except Sto become significant after the merger. None of the $\gamma$ are significant in the long run before the merger, but 5 out of 7 become significant at or above $5 \%$ after the merger. Over all periods, we find that the speed of adjustment increases for more than half of these estimates (one in short, five in medium, and six in the long run of the estimates become absolutely larger after the merger). These results imply that single-directional causality exists before and after the merger, but after the merger, there is a modestly more significant and rapid return to equilibrium. 
Table 5. Linear causality tests for NASDAQ index causing OMX indices.

\begin{tabular}{|c|c|c|c|c|c|c|c|c|c|c|c|c|c|c|}
\hline \multicolumn{15}{|c|}{ Panel A: One Year Before and after Stock Exchange Merger } \\
\hline & \multicolumn{2}{|c|}{$\delta$} & \multicolumn{2}{|c|}{$\gamma^{\prime}$} & \multicolumn{2}{|c|}{$\alpha_{1}^{\prime}$} & \multicolumn{2}{|c|}{$\alpha_{2}^{\prime}$} & \multicolumn{2}{|c|}{$\beta_{1}^{\prime}$} & \multicolumn{2}{|c|}{$\beta_{2}^{\prime}$} & \multicolumn{2}{|c|}{ f-Test } \\
\hline & Before & After & Before & After & Before & After & Before & After & Before & After & Before & After & Before & After \\
\hline Cop & -0.450 & -0.927 & & $-0.1724^{* *}$ & $0.069^{* * *}$ & $0.079 * * *$ & $0.032 *$ & 0.004 & $-0.240 * * *$ & $-0.210^{* *}$ & $-0.185^{* *}$ & 0.027 & $4.07^{* * *}$ & $8.39^{* * *}$ \\
\hline Hel & -3.099 & $-7.597^{* *}$ & & -0.0007 & $0.661^{* * *}$ & $0.570^{* * *}$ & $0.360^{* * *}$ & 0.132 & $-0.305^{* * *}$ & $-0.329^{* * *}$ & $-0.216^{* *}$ & -0.128 & $5.81^{* * *}$ & $5.13^{* * *}$ \\
\hline Riga & -0.527 & -0.721 & & $-0.0286^{* *}$ & $0.047^{* * *}$ & $0.052 * * *$ & 0.026 & -0.003 & -0.072 & -0.056 & 0.068 & 0.229 & $3.15^{* * *}$ & $4.11^{* * *}$ \\
\hline Sto & -1.709 & 0.601 & & $-0.0679 * *$ & $0.179 * *$ & $0.225^{* * *}$ & 0.045 & $0.089 * *$ & $-0.232 * *$ & $-0.398^{* * *}$ & -0.080 & -0.163 & $2.71^{* * *}$ & $4.94^{* * *}$ \\
\hline Vil & -0.189 & $-0.913 * *$ & -0.0237 * & $-0.0751^{* * *}$ & $0.050 * * *$ & $0.038^{* * *}$ & -0.019 & $-0.018 *$ & $0.194^{* * *}$ & 0.104 & -0.101 & $0.141 *$ & $4.27^{* * *}$ & $6.58^{* * *}$ \\
\hline Tal & -0.885 & $-1.498^{* *}$ & & $-0.0746^{* * *}$ & $0.088^{* * *}$ & $0.059 * * *$ & 0.011 & -0.008 & $0.153^{* *}$ & 0.016 & -0.058 & 0.132 & $3.55^{* * *}$ & $6.72 * * *$ \\
\hline AOMX & $-1.365^{*}$ & $-2.767 * * *$ & & 0.0001 & $0.177^{* * *}$ & $0.191^{* * *}$ & $0.091 * * *$ & 0.045 & $-0.251 * * *$ & $-0.345^{* * *}$ & $-0.219 * *$ & -0.054 & $6.02 * * *$ & $7.35^{* * *}$ \\
\hline \multicolumn{15}{|c|}{ Panel B: Three Years Before and After Stock Exchange Merger } \\
\hline & \multicolumn{2}{|c|}{$\delta$} & \multicolumn{2}{|c|}{$\gamma$} & \multicolumn{2}{|c|}{$\alpha_{1}$} & \multicolumn{2}{|c|}{$\alpha_{2}$} & \multicolumn{2}{|c|}{$\beta_{1}$} & \multicolumn{2}{|c|}{$\beta_{2}$} & \multicolumn{2}{|c|}{ f-Test } \\
\hline & Before & After & Before & After & Before & After & Before & After & Before & After & Before & After & Before & After \\
\hline Cop & 0.1413 & -0.134 & -0.0059 & $-0.029^{* * *}$ & $0.057^{* * *}$ & $0.071^{* * *}$ & 0.0126 & 0.012 & $-0.136^{* * *}$ & $-0.212^{* * *}$ & -0.072 & -0.059 & $6.07^{* * *}$ & $11.46^{* * *}$ \\
\hline Hel & 1.194 & 0.833 & 0.002 & $-0.023 * *$ & $0.532 * * *$ & $0.398^{* * *}$ & $0.128^{* *}$ & 0.061 & $-0.192 * * *$ & $-0.243^{* * *}$ & -0.068 & -0.062 & $9.72^{* * *}$ & $8.14^{* * *}$ \\
\hline Riga & 0.0046 & 0.134 & -0.012 ** & $-0.012 * * *$ & $0.037^{* * *}$ & $0.041^{* * *}$ & 0.0051 & 0.002 & $0.068^{*}$ & -0.038 & $0.073 *$ & 0.033 & $3.23^{* * *}$ & $5.61 * * *$ \\
\hline Sto & 0.6376 & 0.463 & 0.019 & 0.017 & $0.187^{* * *}$ & $0.159^{* * *}$ & 0.029 & 0.046 & $-0.268^{* * *}$ & $-0.306^{* * *}$ & -0.039 & $-0.159^{* * *}$ & $6.86^{* * *}$ & $6.32 * * *$ \\
\hline Vil & 0.073 & -0.027 & $-0.013^{* *}$ & $-0.014^{* * *}$ & $0.048^{* * *}$ & $0.041^{* * *}$ & $-0.017^{* *}$ & -0.006 & $0.179 * * *$ & $0.107^{* * *}$ & -0.058 & 0.046 & $6.26^{* * *}$ & $10.58^{* * *}$ \\
\hline Tal & 0.261 & -0.224 & -0.005 & $-0.018^{* * *}$ & $0.072 * * *$ & $0.064^{* * *}$ & 0.004 & 0.003 & $0.165^{* * *}$ & 0.018 & -0.004 & $0.091^{* *}$ & $4.74^{* * *}$ & $9.13^{* * *}$ \\
\hline AOMX & 0.264 & -0.223 & $0.012 *$ & $-0.022 * *$ & $0.153^{* * *}$ & $0.131^{* * *}$ & $0.034^{* *}$ & 0.017 & $-0.165^{* * *}$ & $-0.236^{* * *}$ & -0.066 & -0.022 & $10.56^{* * *}$ & $10.51^{* * *}$ \\
\hline \multicolumn{15}{|c|}{ Panel C: Five Years Before and After Stock Exchange Merger } \\
\hline & \multicolumn{2}{|c|}{$\delta$} & \multicolumn{2}{|c|}{$\gamma$} & \multicolumn{2}{|c|}{$\alpha_{1}$} & \multicolumn{2}{|c|}{$\alpha_{2}$} & \multicolumn{2}{|c|}{$\beta_{1}$} & \multicolumn{2}{|c|}{$\beta_{2}$} & \multicolumn{2}{|c|}{ f-Test } \\
\hline & Before & After & Before & After & Before & After & Before & After & Before & After & Before & After & Before & After \\
\hline Cop & 0.165 & 0.103 & -0.0002 & $-0.013 * *$ & $0.042 * * *$ & $0.051^{* * *}$ & 0.006 & $0.012 * *$ & $-0.094^{* * *}$ & $-0.158^{* * *}$ & $-0.058^{*}$ & $-0.065^{*}$ & $6.68^{* * *}$ & $10.43^{* * *}$ \\
\hline Hel & $1.242 *$ & 0.151 & -0.0002 & $-0.008^{* *}$ & $0.400^{* * *}$ & $0.336^{* * *}$ & $0.069^{*}$ & $0.072 *$ & $-0.147^{* * *}$ & -0.211 ** & $-0.060 *$ & -0.061 & $12.79^{* * *}$ & $7.78^{* * *}$ \\
\hline Riga & 0.1703 & -0.143 & -0.001 & $-0.006^{* *}$ & $0.026^{* * *}$ & $0.034^{* * *}$ & 0.004 & 0.003 & 0.041 & $-0.057^{*}$ & $0.066^{* *}$ & 0.041 & $2.09^{* * *}$ & $7.12^{* * *}$ \\
\hline Sto & 0.529 * & 0.077 & 0.007 & -0.006 & $0.149^{* * *}$ & $0.140^{* * *}$ & 0.019 & $0.057^{* * *}$ & $-0.229^{* * *}$ & $-0.281^{* * *}$ & -0.032 & $-0.159^{* *}$ & $9.38^{* * *}$ & $7.37^{* * *}$ \\
\hline
\end{tabular}


Table 5. Cont

\begin{tabular}{|c|c|c|c|c|c|c|c|c|c|c|c|c|c|c|}
\hline \multicolumn{15}{|c|}{ Panel C: Five Years Before and After Stock Exchange Merger } \\
\hline & \multicolumn{2}{|r|}{$\delta$} & \multicolumn{2}{|c|}{$\gamma$} & \multicolumn{2}{|c|}{$\alpha_{1}$} & \multicolumn{2}{|c|}{$\alpha_{2}$} & \multicolumn{2}{|c|}{$\beta_{1}$} & \multicolumn{2}{|c|}{$\beta_{2}$} & \multicolumn{2}{|c|}{ f-Test } \\
\hline & Before & After & Before & After & Before & After & Before & After & Before & After & Before & After & Before & After \\
\hline Vil & 0.149 & -0.171 & -0.003 & $-0.007^{* * *}$ & $0.033 * * *$ & $0.037^{* * *}$ & $-0.010 *$ & -0.004 & $0.165^{* * *}$ & $0.088^{* * *}$ & $-0.051 *$ & 0.0302 & $5.92 * * *$ & $13.86^{* * *}$ \\
\hline Tal & 0.132 & -0.092 & -0.0004 & $-0.005^{*}$ & $0.055^{* * *}$ & $0.065^{* * *}$ & -0.001 & 0.002 & $0.157^{* * *}$ & 0.034 & -0.005 & 0.037 & $5.28^{* * *}$ & $11.87^{* * *}$ \\
\hline AOMX & $0.434^{* *}$ & 0.368 & 0.003 & $-0.008 * *$ & $0.113^{* * *}$ & $0.112 * * *$ & 0.016 & $0.024^{* *}$ & $-0.114^{* * *}$ & $-0.209^{* * *}$ & -0.0498 & -0.054 & $13.4^{* * *}$ & $10.46^{* * *}$ \\
\hline \multicolumn{15}{|c|}{$\begin{array}{l}\text { Using subsamples, namely, one, three, and five years before and after the merger of NASDAQ with OMX, we test causality between NASDAQ and OMX stock indices. This table } \\
\text { shows the } \mathrm{f} \text {-value with the null hypothesis of no causality and the coefficients of the speed of adjustment between OMX indices and the NASDAQ index when the NASDAQ } \\
\text { index is regarded as an independent variable. } \mathrm{m}=\mathrm{n}=10 \text {. The coefficients of the first two lag terms of } \mathrm{X}_{\mathrm{t}} \text { and } \mathrm{Y}_{\mathrm{t}} \text { are reported as well. In addition, ECM is not included in the } \\
\text { model for the one year before the sample as a result of no cointegration. }{ }^{*}, * * \text {, and }{ }^{* * *} \text { denote the significance at } 10 \%, 5 \% \text {, and } 1 \% \text { respectively. Source: author's own calculation. } \\
\Delta \mathrm{Y}_{\mathrm{t}}=\delta+\sum_{\mathrm{i}=1}^{\mathrm{n}} \alpha_{\mathrm{i}} \Delta \mathrm{X}_{\mathrm{t}-\mathrm{i}}+\sum_{\mathrm{j}=1}^{\mathrm{m}} \beta_{\mathrm{j}} \Delta \mathrm{Y}_{\mathrm{t}-\mathrm{j}}+\gamma \cdot \mathrm{ECM}_{\mathrm{t}-1}+\mathrm{u}_{1 \mathrm{t}} \text {. }\end{array}$} \\
\hline \multicolumn{15}{|c|}{ Panel A: One Year Before and After Stock Exchange Merger } \\
\hline & \multicolumn{2}{|c|}{$\delta$} & \multicolumn{2}{|c|}{$\gamma^{\prime}$} & \multicolumn{2}{|c|}{$\alpha_{1}^{\prime}$} & \multicolumn{2}{|c|}{$\alpha_{2}^{\prime}$} & \multicolumn{2}{|c|}{$\boldsymbol{\beta}_{1}^{\prime}$} & \multicolumn{2}{|c|}{$\beta_{2}^{\prime}$} & \multicolumn{2}{|c|}{ f-Test } \\
\hline & Before & After & Before & After & Before & After & Before & After & Before & After & Before & After & Before & After \\
\hline Cop & -0.427 & -5.474 & & 0.4401 & -0.021 & -0.077 & 0.007 & -0.0595 & $-0.819 *$ & -0.358 & 0.678 & -0.728 & 1.34 & 0.74 \\
\hline $\mathrm{Hel}$ & -0.23 & $-8.512 * *$ & & $0.0600 *$ & -0.027 & -0.057 & 0.108 & -0.075 & -0.140 * & -0.107 & 0.036 & -0.047 & 1.43 & 1.01 \\
\hline Riga & -0.678 & $-8.131 *$ & & 0.233 * & -0.125 * & -0.053 & 0.084 & -0.1003 & -0.583 * & -0.885 & -0.185 & $1.155^{* *}$ & 1.07 & 1.49 \\
\hline Sto & 0.203 & -6.841 & & 0.058 & -0.101 & -0.015 & 0.03 & -0.013 & -0.075 & $-0.552 * *$ & 0.107 & -0.283 & 1.19 & 0.85 \\
\hline Vil & 0.639 & -3.45 & 0.148 & $0.607^{* * *}$ & -0.100 & -0.036 & 0.109 & -0.105 & $1.156^{* *}$ & -0.155 & 0.470 & 1.002 & 1.00 & 1.28 \\
\hline Tal & -0.457 & -6.217 & & 0.129 & -0.102 & -0.051 & 0.076 & -0.127 & -0.45 & -0.473 & 0.082 & 0.515 & 0.79 & $1.63 *$ \\
\hline AOMX & -0.511 & $-7.737^{*}$ & & $0.254^{* *}$ & -0.015 & 0.002 & 0.112 & -0.035 & $-0.578^{* *}$ & -0.541 & 0.187 & -0.126 & 1.53 & 1.36 \\
\hline \multicolumn{15}{|c|}{ Panel B: Three Years Before and After Stock Exchange Merger } \\
\hline & \multicolumn{2}{|c|}{$\delta$} & \multicolumn{2}{|c|}{$\gamma^{\prime}$} & \multicolumn{2}{|c|}{$\alpha_{1}^{\prime}$} & \multicolumn{2}{|c|}{$\alpha_{2}^{\prime}$} & \multicolumn{2}{|c|}{$\beta_{1}^{\prime}$} & \multicolumn{2}{|c|}{$\beta_{2}^{\prime}$} & \multicolumn{2}{|c|}{ f-Test } \\
\hline & Before & After & Before & After & Before & After & Before & After & Before & After & Before & After & Before & After \\
\hline Cop & 0.1786 & 0.388 & $0.172 * * *$ & -0.069 & 0.029 & -0.076 & -0.018 & -0.081 & $-0.694 * * *$ & -0.053 & 0.3754 & -0.241 & $2.35^{* * *}$ & 1.29 \\
\hline Hel & 1.125 & 0.732 & 0.0161 & 0.001 & 0.024 & -0.065 & -0.004 & $-0.115^{* *}$ & $-0.096^{* *}$ & 0.002 & 0.0343 & 0.035 & $2.32 * * *$ & 1.48 \\
\hline Riga & 0.8393 & 1.642 & $0.033 *$ & -0.034 & -0.052 & -0.062 & -0.023 & $-0.099 * *$ & -0.0929 & -0.307 & -0.0093 & 0.229 & 1.27 & 1.40 \\
\hline Sto & 1.4674 & 1.934 & $0.045^{* * *}$ & $0.088^{* * *}$ & -0.027 & -0.018 & -0.037 & -0.078 & -0.0908 & -0.204 & 0.0626 & -0.076 & $2.07^{* *}$ & $1.98^{* *}$ \\
\hline Vil & 0.596 & 0.932 & 0.042 & -0.014 & -0.044 & 0.001 & 0.303 & $-0.107^{* *}$ & $-0.501^{* *}$ & -0.128 & 0.303 & 0.373 & 1.22 & 0.83 \\
\hline Tal & -0.047 & 1.145 & 0.012 & 0.018 & -0.048 & -0.045 & -0.024 & $-0.100 * *$ & -0.095 & -0.153 & 0.064 & 0.178 & 1.13 & 1.31 \\
\hline AOMX & 0.638 & 0.782 & $0.063^{* * *}$ & 0.008 & 0.024 & -0.044 & -0.001 & $-0.106^{*}$ & $-0.346^{* *}$ & -0.084 & 0.1601 & 0.117 & $2.71^{* * *}$ & $1.60 *$ \\
\hline
\end{tabular}


Table 6. Cont.

\begin{tabular}{|c|c|c|c|c|c|c|c|c|c|c|c|c|c|c|}
\hline \multicolumn{15}{|c|}{ Panel C: Five Years Before and After Stock Exchange Merger } \\
\hline & \multicolumn{2}{|c|}{$\delta$} & \multicolumn{2}{|c|}{$\gamma^{\prime}$} & \multicolumn{2}{|c|}{$\alpha_{1}^{\prime}$} & \multicolumn{2}{|c|}{$\alpha_{2}^{\prime}$} & \multicolumn{2}{|c|}{$\beta_{1}^{\prime}$} & \multicolumn{2}{|c|}{$\beta_{2}^{\prime}$} & \multicolumn{2}{|c|}{ f-Test } \\
\hline & Before & After & Before & After & Before & After & Before & After & Before & After & Before & After & Before & After \\
\hline Cop & $1.471^{* *}$ & 0.924 & $0.060^{* *}$ & -0.017 & 0.008 & -0.054 & -0.022 & -0.036 & $-0.480 * *$ & -0.081 & $0.483^{* *}$ & -0.273 & $2.59 * * *$ & 0.90 \\
\hline $\mathrm{Hel}$ & 1.036 & 1.227 & $0.009 * * *$ & -0.002 & 0.009 & -0.056 & -0.013 & $-0.100 * *$ & $-0.063 *$ & 0.005 & 0.043 & 0.067 & $2.29 * * *$ & $1.58 *$ \\
\hline Riga & 1.073 & 0.974 & $0.028 * * *$ & -0.028 & -0.029 & $-0.052 *$ & -0.008 & $-0.060 *$ & -0.062 & -0.214 & -0.0201 & $0.350 *$ & $1.74 *$ & 1.36 \\
\hline Sto & $1.533^{* *}$ & 1.202 & $0.031 * * *$ & 0.016 & -0.024 & -0.019 & -0.033 & -0.0597 & -0.015 & -0.128 & 0.078 & 0.009 & $1.97^{* *}$ & 1.12 \\
\hline Vil & 0.994 & 0.851 & 0.017 & -0.007 & -0.027 & $-0.067^{* *}$ & -0.0001 & $-0.082 * *$ & $-0.374 * *$ & 0.313 & 0.277 & 0.32003 & 1.30 & 0.70 \\
\hline Tal & $1.338^{*}$ & 0.755 & $0.019^{* * *}$ & -0.005 & -0.024 & -0.058 * & -0.013 & $-0.069 * *$ & -0.077 & 0.034 & 0.068 & 0.094 & $2.06^{* *}$ & 0.75 \\
\hline AOMX & $1.616^{* *}$ & 1.256 & $0.025^{* * *}$ & -0.005 & 0.004 & -0.044 & -0.019 & $-0.087^{* *}$ & -0.198 * & -0.044 & 0.209 * & 0.178 & $2.27 * * *$ & 1.31 \\
\hline
\end{tabular}

Using subsamples, namely, one, three, and five years before and after the merger of NASDAQ with OMX, we test causality between NASDAQ and OMX stock indices. This table shows the $\mathrm{f}$-value with the null hypothesis of no causality and the coefficients of the speed of adjustment between OMX indices and the NASDAQ index when the NASDAQ index is regarded as a dependent variable. $\mathrm{m}=\mathrm{n}=10$. The coefficients of the first two lag terms of $X_{t}$ and $Y_{t}$ are reported as well. In addition, $E C M$ is not included in the model for the one year before the sample as a result of no cointegration. ${ }^{*}, * *$, and ${ }^{* * *}$ denote the significance at $10 \%, 5 \%$, and $1 \%$, respectively. Source: author's own calculation. $\Delta \mathrm{X}_{\mathrm{t}}=\delta+\sum_{\mathrm{i}=1}^{\mathrm{n}} \alpha^{\prime}{ }_{\mathrm{i}} \Delta \mathrm{X}_{\mathrm{t}-\mathrm{i}}+\sum_{\mathrm{i}=1}^{\mathrm{m}} \beta^{\prime}{ }_{\mathrm{j}} \Delta \mathrm{Y}_{\mathrm{t}-\mathrm{j}}+\gamma^{\prime} \cdot \mathrm{ECM}_{\mathrm{t}-1}+\mathrm{u}_{2 \mathrm{t}}$. 
Looking at the results of Table 6, which tests the model in Equation (4), we are unable to reject the null hypothesis that OMX indices do not Granger-cause the NASDAQ index one year before/after the merger at the $5 \%$ significant level (see $\mathrm{f}-$ value in the Table 6). Thus, we are unable to conclude whether there is a positive or negative effect on the predictive power of the OMX indices on the NASDAQ index in the short run. In the medium run, Cop/Hel only Granger-causes the NASDAQ index before the merger and Sto Granger-causes the NASDAQ both before and after the merger. The implication is that after the merger, some OMX indices lose their predictive power on NASDAQ. In the long run, 5 out of 7 of the statistics of the $\mathrm{f}$-test for OMX indices that Granger-cause the NASDAQ before the merger become insignificant after the merger. When we check the estimates of the error-correction coefficient, except for Vil, it is not significant in the short run before the merger. After the merger, two coefficients become significant. In the medium term, two estimates go from insignificant before the merger to significant after the merger. In the long run, six out of seven estimates go from significant to insignificant. Furthermore, four estimates of the error-correction coefficient in the medium run and six in the long run become absolutely smaller after the merger. These findings show that (1) the relationship of OMX causing NASDAQ only exists in the relatively longer time period before the merger, (2) the error-correction mechanism only exists in the short run after the merger and in the long run before the merger, and (3) NASDAQ index seems to return to the long-run equilibrium more slowly in the long run.

\subsection{Nonlinear Causality}

To test the existence of strictly nonlinear causal relationships between the NASDAQ and OMX indices, we employed the nonlinear nonparametric causality test with $\mathrm{m}=1, \mathrm{~L}_{\mathrm{x}}=\mathrm{L}_{\mathrm{y}}=10, \mathrm{e}=1.5$. Table 7 shows the results of the nonlinear causality before and after the merger. We first look into the results of Panel A, which is based on the null hypothesis that NASDAQ does not nonlinearly cause OMX. We find only one rejection of noncausality at the 5\% level before the merger in the short, medium, and long runs, while after the merger, NASDAQ nonlinear noncausality is never rejected at the $5 \%$ level in the short run. In the medium and long run, it is rejected three times each. In Panel B, we consider the opposite directional nonlinear causality between NASDAQ and OMX. As in Panel A, the number of significant rejections at or above the $5 \%$ level after the merger diminish in the short run but increase in the medium and long runs. These findings imply that the causality between NASDAQ and OMX becomes more complex after the merger in the medium and long runs.

Combining the results of linear and nonlinear causality, we find that (1) before the merger, NASDAQ and OMX have bidirectional causal relations in the long run and unidirectional relations in the short run, and these relations are primarily linear. (2) After the merger, the error-correction mechanism pushing OMX back to long-run equilibrium works better and more significantly; it does not work for NASDAQ. (3) After the merger in the medium and long runs, the causal relation of OMX causing NASDAQ becomes nonlinear. These results hint that NASDAQ and OMX operated independently before the merger. However, after the merger, NASDAQ and OMX operate as a group or a team. NASDAQ performs like a leader, and OMX performs like a follower. The predictive power of OMX on NASDAQ becomes weaker and nonlinear after the merger. Additionally, OMX, instead of NASDAQ, becomes the one who is responsible for adjusting and returning to the long equilibrium. 
Table 7. Nonlinear causality tests using the daily price index of OMX and NASDAQ.

\begin{tabular}{|c|c|c|c|c|c|c|}
\hline \multicolumn{7}{|c|}{ Panel A } \\
\hline \multirow{2}{*}{\multicolumn{7}{|c|}{$\begin{array}{c}\operatorname{Pr}\left(\left\|y_{t}^{m}-y_{s}^{m}\right\|<e\left\|y_{t-L y}^{L y}-y_{s-L y}^{L y}\right\|<e,\left\|x_{t-L x}^{L x}-x_{s-L x}^{L x}\right\|<e\right)=\operatorname{Pr}\left(\left\|y_{t}^{m}-y_{s}^{m}\right\|<e\left\|y_{t-L y}^{L y}-y_{s-L y}^{L y}\right\|<e\right) \\
\text { 1 Year }\end{array}$}} \\
\hline & & & & & & \\
\hline \multirow{2}{*}{\multicolumn{7}{|c|}{$\begin{array}{l}\text { Dependent } \\
\text { Variables }\end{array}$}} \\
\hline & \multicolumn{6}{|c|}{ Variables } \\
\hline Cop & 0.1649 & 0.2266 & 0.4239 & 0.0704 * & 0.1512 & $0.0604 *$ \\
\hline Hel & 0.3267 & 0.4178 & 0.1305 & $0.0025^{* * *}$ & 0.1941 & $0.0305^{* *}$ \\
\hline Riga & 0.4869 & 0.0685 * & 0.2962 & 0.3035 & $0.0271^{* *}$ & 0.3104 \\
\hline Sto & $0.0636 *$ & 0.4741 & $0.0336^{* *}$ & $0.0000 * * *$ & $0.0846 *$ & $0.0000^{* * *}$ \\
\hline Vil & 0.325 & 0.1763 & 0.1538 & 0.2329 & 0.1435 & 0.4721 \\
\hline Tal & $0.0418^{* *}$ & 0.1263 & $0.0873 *$ & 0.2892 & 0.2878 & 0.2008 \\
\hline AOMX & 0.2191 & 0.3429 & 0.1434 & $0.0218^{* *}$ & 0.4761 & $0.0137^{* *}$ \\
\hline \multicolumn{7}{|c|}{ Panel B } \\
\hline \multicolumn{7}{|c|}{$\begin{array}{c}\operatorname{Pr}\left(\left\|x_{t}^{m}-x_{s}^{m}\right\|<e\|\| x_{t-L x}^{L x}-x_{s-L x}^{L x}\|<e,\| y_{t-L y}^{L y}-y_{s-L y}^{L y} \|<e\right)=\operatorname{Pr}\left(\left\|x_{t}^{m}-x_{s}^{m}\right\|<e \mid\left\|x_{t-L x}^{L x}-x_{s-L x}^{L x}\right\|<e\right) \\
1 \text { Year }\end{array}$} \\
\hline & Before & After & Before & After & Before & After \\
\hline \multicolumn{7}{|l|}{ Independent } \\
\hline \multicolumn{7}{|l|}{ Variables } \\
\hline Cop & $0.0011^{* * *}$ & 0.4368 & 0.1107 & $0.0009 * * *$ & 0.4135 & $0.0011^{* * *}$ \\
\hline Hel & 0.1193 & $0.0293^{* *}$ & 0.1146 & $0.0010^{* * *}$ & 0.1699 & $0.0004^{* * *}$ \\
\hline Riga & $0.0292 * *$ & 0.3557 & $0.0654^{*}$ & 0.1902 & $0.0369 * *$ & 0.1796 \\
\hline Sto & 0.2275 & 0.4241 & $0.0126^{* *}$ & $0.0000^{* * *}$ & 0.1231 & $0.0000 * * *$ \\
\hline Vil & 0.3818 & 0.3097 & 0.2066 & 0.3410 & $0.0048^{* * *}$ & $0.0266^{* *}$ \\
\hline Tal & 0.2037 & $0.0842 *$ & $0.0049 * * *$ & 0.2266 & 0.1196 & 0.4031 \\
\hline AOMX & 0.2269 & 0.3515 & $0.0208^{* *}$ & 0.0101 ** & 0.4587 & $0.0001^{* * *}$ \\
\hline
\end{tabular}

Using the residuals from Tables 5 and 6 , we test causality between NASDAQ and OMX stock indices. This table shows $\mathrm{p}$-values with the null hypothesis of no nonlinear causality between the Nordic stock indices and the NASDAQ index when the NASDAQ index is regarded as a dependent variable and an independent variable separately. $\mathrm{m}=1, \mathrm{~L}_{\mathrm{x}}=\mathrm{L}_{\mathrm{y}}=10, \mathrm{e}=1.5{ }^{*}, * *$, and ${ }^{* * *}$ denote the significance at $10 \%, 5 \%$, and $1 \%$ levels, respectively. Source: author's own calculation, using $C$ programs software.

\subsection{Mean-Variance and Mean Omega Analysis}

We now turn to the question of whether and how the performance of the indices changes after the merger. Table 8 presents the basic statistics and Omega ratios for the daily stock excess returns of the stock indices from Euronext OMX in the short, medium, and long runs. Except for Tal and NASDAQ in the medium term, we find that the mean returns before the merger are higher than those after the merger. However, except for Vil in the short/long run, none of the coefficients are significant at the $5 \%$ level or better. Thus, we conclude (1) that there is no premerger or postmerger outperformance. On the other hand, the standard deviations of each index are larger after the merger. Among them, the $\mathrm{F}$-statistics of the return between pre- and postmerger are all significant at the $1 \%$ significance level. This result infers that investors suffer more volatility after the merger when they invest in the OMX markets. All the Omega ratios with the threshold return of $0.00 \%$ are larger in the premerger period, showing a lower probability of earning positive profits after the merger. These results are consistent across the different time periods included in the sample. When we set the threshold return, $-0.50 \%$, the Omega ratios of the OMX and NASDAQ indices after the merger are much smaller than they are before the merger. However, when we set the threshold return relatively higher, at $0.50 \%$, all Omega ratios are higher in the postmerger period except Vil in the long run. These findings imply that it is easier for investors to earn positive profits or control losses before the merger, but investors enjoy a higher probability of achieving a relatively high return after the merger. According to the three points above, we conclude that there is no existence of significant change in the mean of performance and that risk-averters prefer to invest before the merger to control risk while risk-seekers prefer to invest after the merger to earn a higher return. 
Table 8. Descriptive statistics of the returns for the MV criterion and Omega ratio.

\begin{tabular}{|c|c|c|c|c|c|c|c|}
\hline \multicolumn{8}{|l|}{1 Year } \\
\hline \multirow{2}{*}{\multicolumn{2}{|c|}{ Variable }} & Mean & StdDev & t-Test & Omega (\%) & Omega (\%) & Omega (\%) \\
\hline & & $(\%)$ & $(\%)$ & F-Test & $r=0.0 \%$ & $\mathrm{r}=-0.5 \%$ & $r=0.5 \%$ \\
\hline \multirow{2}{*}{ Cop } & Before & -0.05 & 1.34 & 1.04 & 89.89 & 234.47 & 30.47 \\
\hline & After & -0.27 & 2.78 & $4.34^{* * *}$ & 75.53 & 126.38 & 45.38 \\
\hline \multirow{2}{*}{ Hel } & Before & -0.04 & 1.42 & 1.49 & 91.32 & 228.64 & 35.23 \\
\hline & After & -0.36 & 2.69 & $3.60^{* * *}$ & 69.16 & 115.72 & 41.88 \\
\hline \multirow{2}{*}{ Riga } & Before & -0.09 & 1.28 & $1.96^{*}$ & 79.19 & 261.18 & 23.47 \\
\hline & After & -0.43 & 2.13 & $2.76^{* * *}$ & 55.37 & 110.06 & 28.51 \\
\hline \multirow[b]{2}{*}{ Sto } & Before & -0.09 & 1.45 & 0.43 & 84.43 & 203.10 & 33.49 \\
\hline & After & -0.19 & 2.83 & $3.83 * * *$ & 83.12 & 135.94 & 51.45 \\
\hline \multirow{2}{*}{ Vil } & Before & -0.03 & 1.08 & $2.77^{* * *}$ & 91.01 & 313.01 & 21.84 \\
\hline & After & -0.51 & 2.22 & $4.20^{* * *}$ & 47.62 & 99.37 & 23.43 \\
\hline \multirow{2}{*}{ Tal } & Before & -0.14 & 1.17 & $1.70 *$ & 69.66 & 236.48 & 20.09 \\
\hline & After & -0.41 & 2 & $2.94^{* * *}$ & 54.86 & 113.69 & 27.29 \\
\hline \multirow[b]{2}{*}{ AOMX } & Before & -0.08 & 0.93 & $1.93^{*}$ & 78.97 & 316.27 & 14.40 \\
\hline & After & -0.36 & 1.92 & $4.29^{* * *}$ & 57.59 & 123.40 & 27.56 \\
\hline \multirow{2}{*}{ NASDAQ } & Before & -0.01 & 1.25 & 1.08 & 98.93 & 259.56 & 33.58 \\
\hline & After & -0.24 & 2.92 & $5.45^{* * *}$ & 79.46 & 128.01 & 49.27 \\
\hline \multicolumn{8}{|l|}{3 Year } \\
\hline \multirow{2}{*}{\multicolumn{2}{|c|}{ Variable }} & Mean & StdDev & t-Test & Omega (\%) & Omega (\%) & Omega (\%) \\
\hline & & $(\%)$ & $(\%)$ & F-Test & $r=0.0 \%$ & $\mathrm{r}=-0.5 \%$ & $r=0.5 \%$ \\
\hline \multirow{2}{*}{ Cop } & Before & 0.04 & 1.09 & 0.29 & 110.59 & 353.97 & 29.79 \\
\hline & After & 0.02 & 1.97 & $3.26^{* * *}$ & 102.25 & 211.69 & 49.12 \\
\hline \multirow{2}{*}{ Hel } & Before & 0.05 & 1.15 & 0.58 & 112.29 & 351.83 & 33.15 \\
\hline & After & 0.00 & 2.04 & $3.13^{* * *}$ & 99.33 & 194.90 & 50.16 \\
\hline \multirow{2}{*}{ Riga } & Before & 0.04 & 1.12 & 0.75 & 111.32 & 403.62 & 30.40 \\
\hline & After & -0.02 & 1.95 & $3.03^{* * *}$ & 96.49 & 197.98 & 47.35 \\
\hline \multirow{2}{*}{ Sto } & Before & 0.03 & 1.20 & 0.06 & 107.49 & 318.49 & 33.07 \\
\hline & After & 0.02 & 2.01 & $2.79 * * *$ & 103.70 & 210.20 & 51.28 \\
\hline \multirow{2}{*}{ Vil } & Before & 0.05 & 1.05 & 0.82 & 113.19 & 401.11 & 28.71 \\
\hline & After & -0.02 & 1.74 & $2.73 * * *$ & 96.52 & 237.63 & 38.91 \\
\hline Tal & Before & 0.024 & 0.96 & -0.03 & 108.67 & 462.05 & 21.78 \\
\hline lal & After & 0.026 & 1.74 & $3.29^{* * *}$ & 104.45 & 238.01 & 46.26 \\
\hline AOMX & Before & 0.04 & 0.73 & 0.57 & 106.73 & 465.4 & 21.67 \\
\hline & After & 0.00 & 1.42 & $3.80^{* * *}$ & 100.63 & 270.29 & 36.12 \\
\hline NASDAQ & Before & 0.02 & 1.03 & -0.08 & 106.07 & 366.82 & 28.53 \\
\hline & After & 0.03 & 2.03 & $3.89 * * *$ & 104.47 & 209.82 & 49.96 \\
\hline 5 year & & & & & & & \\
\hline Var & & Mean & StdDev & t-Test & Omega (\%) & Omega (\%) & Omega (\%) \\
\hline & & $(\%)$ & $(\%)$ & F-Test & $r=0.0 \%$ & $r=-0.5 \%$ & $r=0.5 \%$ \\
\hline Con & Before & 0.07 & 1.03 & 0.86 & 120.81 & 419.47 & 31.82 \\
\hline cop & After & 0.02 & 1.72 & $2.78^{* * *}$ & 103.73 & 237.24 & 44.42 \\
\hline & Before & 0.07 & 1.09 & 1.29 & 120.31 & 397.98 & 33.90 \\
\hline Hel & After & -0.01 & 1.95 & $3.21^{* * *}$ & 98.34 & 197.97 & 48.61 \\
\hline Riga & Before & 0.09 & 1.03 & $1.96^{*}$ & 128.60 & 517.14 & 31.93 \\
\hline Kiga & After & -0.02 & 1.61 & $2.41^{* * *}$ & 95.66 & 234.75 & 38.73 \\
\hline & Before & 0.06 & 0.04 & 0.64 & 115.11 & 344.07 & 36.18 \\
\hline Sto & After & 0.02 & 0.05 & $2.41^{* * *}$ & 103.22 & 220.96 & 47.66 \\
\hline Vil & Before & 0.14 & 1.02 & $2.98^{* * *}$ & 148.06 & 539.84 & 36.49 \\
\hline VII & After & -0.02 & 1.51 & $2.21^{* * *}$ & 95.42 & 275.33 & 32.47 \\
\hline & Before & 0.10 & 0.98 & 1.53 & 136.38 & 544.33 & 29.91 \\
\hline Tal & After & 0.02 & 1.54 & $2.48^{* * *}$ & 103.13 & 266.04 & 40.24 \\
\hline & Before & 0.09 & 0.67 & $2.10^{* *}$ & 145.05 & 858.89 & 16.05 \\
\hline AUMX & After & 0.00 & 1.26 & $3.55^{* * *}$ & 100.04 & 303.93 & 31.19 \\
\hline NASDAQ & Before & 0.05 & 1.11 & 0.35 & 112.76 & 353.28 & 34.32 \\
\hline NASDAQ & After & 0.03 & 1.78 & $2.56^{* * *}$ & 104.94 & 232.67 & 45.46 \\
\hline
\end{tabular}

Using subsamples, namely, one/three/five years before and after the merger of NASDAQ with OMX, we report the mean-variance of the daily return of the stock index. This table shows the results of the t-test and the f-test with the null hypothesis that the mean and volatility of the stock index are different pre- and postmerger. Omega ratios with different returns, i.e., $0.00 \%,-0.50 \%, 0.50 \%$, are shown as well. ${ }^{*}$ and ${ }^{* * *}$ denote the significance at $10 \%$ and $1 \%$ levels, respectively. Source: author's own calculation. 


\section{Conclusions}

This paper investigates how the stock exchange merger of NASDAQ with OMX affects the comovement between the stock markets of OMX and NASDAQ and briefly examines whether the merger reduces investor utility by reducing diversification opportunities.

Some players in the market may not realize that stock exchanges were created like mutual organizations and owned by its member stockbrokers, but some players in the markets have demutualized and their members sell their shares in an initial public offering. Actually, stock exchanges are run like normal private companies and try to increase the wealth of the shareholders as much as possible. Thus, the principal question is, do they care about the sustainable development of investments, allowing investors to diversify their investments and reduce the risk of their investments? In this regard, we are interested in whether it is necessary to set up some national policies and international treaties for sustainable development and to implement and monitor policies for the sustainable development of stock markets.

We find that the comovement between indices in the OMX and NASDAQ indices adjusts due to the merger. The cointegration test shows that the long-run common trend exists one year after the merger but not one year before the merger, implying that the merger improves the integration of the two stock exchanges, which, in turn, implies that the merger of NASDAQ and OMX becomes more sustainable. The results are congruent with Choudhry et al. [17], Kearney and Lucey [18], and Chen et al. [19], in that cointegrated stock markets weaken the benefits of international portfolio diversification in the long run.

Using Granger causality with ECM, we find that the error-correction mechanism for NASDAQ causing OMX indices becomes significant after the merger, providing further evidence of the improvement of integration after the merger. However, the causal relation from OMX to NASDAQ becomes insignificant and/or nonlinear after the merger. These findings show that the relationship between the two exchanges changes after the merger.

Finally, our study shows that the volatility of stock returns seems to be higher, with no clear rise of mean after the merger. In addition, the probability that a low threshold return will be achieved becomes lower after the merger, implying that it is difficult for investors to control risk as a result of the decreased diversification opportunities after the merger; however, the probability of achieving a relatively high target return becomes higher.

Our finding confirms that the merger increases in the long-run comovement between each pair of indices in Nordic and Baltic stock markets, implying that the merger of NASDAQ and OMX reduced the diversification possibilities for investors in stock markets and inferring that it is important to implement national policies and international treaties for the sustainable development of financial markets. As already mentioned, Otchere and Abukari [4] examined whether stock exchange mergers could increase efficiency or if these stock exchanges mergers are only a question of market power, finding that the industry's concentration levels have not significantly increased and the concentration levels do not influence the exchanges' profitability in the postmerger period. Our investigation complements the Otchere and Abukari [4] findings, describing that stock exchange mergers do not benefit stock market investors in terms of portfolio diversion.

One limitation of our study is that we have not compared other mergers of stock exchanges that have occurred in history. An extension of our study could compare other mergers of stock exchanges that have occurred in history to check whether the effects of other mergers are the same as those in our study and whether the effects have changed from time to time. Another limitation of our study is that we have not explored, at the same time, whether the wealth of Euronext shareholders increased after the merger with OMX. An extension of our study could also study the change in the wealth of the shareholders after the mergers.

This paper investigates the stock exchange merger of NASDAQ with OMX and examines the sustainability of co-movement between the stock markets of OMX and NASDAQ, that could affect investors' profit and decision making in their investment, changing their trading strategies, 
and could affect market efficiency and create arbitrage opportunity, anomaly, and additional risk. Thus, extension of our paper could include studying co-movement of other series [55,58-71], co-movement of using different trading strategies [47,72-75], co-movement of making use of different anomalies [76-78], co-movement of investing in different markets [60,64,79-82], sustainability of making use of different market conditions [66,83], and co-movement in different types of risk [84-97]. To do so, we have to apply some advanced statistics, see, for example, Bai, et al., [43-46], Hui, et al. [87], Ng, et al. [88], and Guo, et al. [89-91].

Author Contributions: Conceptualization, J.P.V. and W.X.; methodology, W.X. and W.-K.W.; software, W.X.; validation, J.P.V., E.C., W.X. and W.-K.W.; formal analysis, W.X.; investigation, J.P.V., E.C., W.X. and W.-K.W.; resources, J.P.V. and W.X.; data curation, J.P.V. and W.X.; writing-original draft preparation, J.P.V., E.C., W.X. and W.-K.W.; writing-review and editing, J.P.V., E.C., W.X. and W.-K.W.; visualization, J.P.V., E.C., W.X. and W.-K.W.; supervision, J.P.V., E.C., and W.-K.W.; project administration, J.P.V., E.C., W.X. and W.-K.W.; funding acquisition, J.P.V., E.C., W.X. and W.-K.W. All authors have read and agreed to the published version of the manuscript.

Funding: The research is partially supported by Asia University, China Medical University Hospital, Hang Seng University of Hong Kong, and the Ministry of Science and Technology (MOST) (Project Numbers 106-2410-H-468-002 and 107-2410-H-468-002-MY3).

Acknowledgments: The authors would like to thank the Editor, Editor Assistant for their guidance and follow-up. Also, authors would like to thank the anonymous referee for their valuable comments that's enhance our paper to appear in its current format. The fourth author would like to thank Robert B. Miller and Howard Thompson for their continuous guidance and encouragement.

Conflicts of Interest: The authors declare no conflict of interest.

\section{References}

1. McAndrews, J.; Stefanadis, C. The consolidation of european stock exchanges. Curr. Issues Econ. Financ. 2002, 8, 1-6.

2. Di Noia, C. Competition and integration among stock exchanges in europe: Network effects, implicit mergers and remote access. Eur. Financ. Manag. 2001, 7, 39-72. [CrossRef]

3. Jain, P.K. Financial market design and the euity premium: Electronic versus floor trading. J. Financ. 2005, 60, 2955-2985. [CrossRef]

4. Otchere, I.; Abukari, K. Are super stock exchange mergers motivated by efficiency or market power gains? J. Int. Financ. Mark. Inst. Money 2020, 64. [CrossRef]

5. Santos, T.; Scheinkman, J.A. Competition among exchanges. Q. J. Econ. 2001, 116, 1027-1061. [CrossRef]

6. Nielsson, U. Stock exchange merger and liquidity. J. Financ. Mark. 2009, 12, 229-267. [CrossRef]

7. Kokkoris, I.; Olivares-Caminal, R. Lessons from the recent stock exchange merger activity. J. Compet. Law Econ. 2008, 4, 837-869. [CrossRef]

8. Pagano, M. Trading volume and asset liquidity. Q. J. Econ. 1989, 104, 255-274. [CrossRef]

9. Steil, B. Borderless Trading and Developing Securities Markets. Open Doors: Foreign Participation in Financial Systems in Developing Countries; Brookings Institution Press: Washington, DC, USA, 2001; Volume 6, pp. 327-350.

10. Amihud, Y.; Mendelson, H. Asset pricing and the bid-ask spread. J. Financ. Econ. 1986, 17, 223-249. [CrossRef]

11. Brennan, M.J.; Subrahmanyam, A. Market microstructure and asset pricing: On the compensation for illiquidity in stock returns. J. Financ. Econ. 1996, 41, 441-464. [CrossRef]

12. Datar, V.T.; Naik, N.Y.; Radcliffe, R. Liquidity and stock returns: An alternative test. J. Financ. Mark. 1998, 1, 203-219. [CrossRef]

13. Hasan, I.; Schmiedel, H.; Song, L. Growth strategies and value creation: What works best for stock exchanges? Financ. Rev. 2012, 47, 469-499. [CrossRef]

14. Rua, A.; Nunes, L.C. International comovement of stock market returns: A wavelet analysis. J. Empir. Financ. 2009, 16, 632-639. [CrossRef]

15. Ali, S.; Butt, B.Z.; Rehman, K. Comovement between emerging and developed stock markets: An investigation through cointegration analysis. World Appl. Sci. J. 2011, 12, 395-403.

16. Gilmore, C.G.; McManus, G.M. International portfolio diversification: US and Central European equity markets. Emerg. Mark. Rev. 2002, 3, 69-83. [CrossRef] 
17. Grubel, H.G. Internationally diversified portfolios: Welfare gains and capital flows. Am. Econ. Rev. 1968, $58,1299-1314$.

18. Choudhry, T.; Lu, L.; Peng, K. Common stochastic trends among Far East stock prices: Effects of the Asian financial crisis. Int. Rev. Financ. Anal. 2007, 16, 242-261. [CrossRef]

19. Kearney, C.; Lucey, B. International equity market integration: Theory, evidence and implications. Int. Rev. Financ. Anal. 2004, 13, 571-583. [CrossRef]

20. Chen, G.-M.; Firth, M.; Rui, O.M. Stock market linkages: Evidence from Latin America. J. Bank. Financ. 2002, 26, 1113-1141. [CrossRef]

21. Brooks, R.; Del Negro, M. The rise in comovement across national stock markets: Market integration or IT bubble? J. Empir. Financ. 2004, 11, 659-680. [CrossRef]

22. Brooks, R.; Del Negro, M. Firm-Level evidence on international stock market comovement*. Rev. Financ. 2006, 10, 69-98. [CrossRef]

23. King, M.; Sentana, E.; Wadhwani, S. Volatility and links between national stock markets. Econometrica 1994, 62, 901. [CrossRef]

24. Longin, F.; Solnik, B. Is the correlation in international equity returns constant: 1960-1990? J. Int. Money Financ. 1995, 14, 3-26. [CrossRef]

25. Longin, F.; Solnik, B. Extreme correlation of international equity markets. J. Financ. 2001, 56, 649-676. [CrossRef]

26. Lin, W.-L.; Engle, R.F.; Ito, T. Do bulls and bears move across borders? International transmission of stock returns and volatility. Rev. Financ. Stud. 1994, 7, 507-538. [CrossRef]

27. Karolyi, G.A.; Stulz, R.M. Why do markets move together? An investigation of US-Japan stock return comovements. J. Financ. 1996, 51, 951-986. [CrossRef]

28. Forbes, K.J.; Rigobon, R. No contagion, only interdependence: Measuring stock market comovements. J. Financ. 2002, 57, 2223-2261. [CrossRef]

29. Candelon, B.; Piplack, J.; Straetmans, S. On measuring synchronization of bulls and bears: The case of East Asia. J. Bank. Financ. 2008, 32, 1022-1035. [CrossRef]

30. A'Hearn, B.; Woitek, U. More international evidence on the historical properties of business cycles. J. Monet. Econ. 2001, 47, 321-346. [CrossRef]

31. Pakko, M.R. A spectral analysis of the cross-country consumption correlation puzzle. Econ. Lett. 2004, 84, 341-347. [CrossRef]

32. Smith, K.L. Pre- and post-1987 crash frequency domain analysis among Pacific Rim equity markets. J. Multinatl. Financ. Manag. 2001, 11, 69-87. [CrossRef]

33. Hassan, M.; Naka, A. Short-run and long-run dynamic linkages among international stock markets. Int. Rev. Econ. Financ. 1996, 5, 387-405. [CrossRef]

34. Charles, A.; Darné, O.; Kim, J.H.; Redor, E. Stock exchange mergers and market efficiency. Appl. Econ. 2015, 48, 576-589. [CrossRef]

35. Engle, R.F.; Granger, C.W.J. Co-integration and error correction: Representation, estimation, and testing. Econometrica 1987, 55, 251. [CrossRef]

36. Granger, C.W.J. Investigating causal relations by econometric models and cross-spectral methods. Econometrica 1969, 37, 424. [CrossRef]

37. Billio, M.; Getmansky, M.; Lo, A.; Pelizzon, L. Econometric measures of connectedness and systemic risk in the finance and insurance sectors. J. Financ. Econ. 2012, 104, 535-559. [CrossRef]

38. Jin, T.; Kim, J. Coal consumption and economic growth: Panel cointegration and causality evidence from OECD and Non-OECD countries. Sustainability 2018, 10, 660. [CrossRef]

39. Baek, E.; Brock, W. A General Test for Nonlinear Granger Causality: Bivariate Model. In Iowa State University and University of Wisconsin at Madison Working Paper; 1992. Available online: https: //www.google.com.hk/url?sa=t\&rct=j\&q=\&esrc=s\&source=web\&cd=\&ved=2ahUKEwjazvqcl7HsAhVMqwKHZkFCV8QFjAAegQIARAC\&url=http $\% 3 \mathrm{~A} \% 2 \mathrm{~F} \% 2 \mathrm{Fwww.ssc}$.wisc.edu $\% 2 \mathrm{~F} \sim\{\}$ wbrock $\% 2 \mathrm{FBaek} \%$ 2520Brock\%2520Granger.pdf\&usg=AOvVaw2k461Lvic0GdVrysF_8axj (accessed on 4 August 2020).

40. Denker, M.; Keller, G. On U-statistics and v. mise? statistics for weakly dependent processes. Probab. Theory Relat. Fields 1983, 64, 505-522. [CrossRef]

41. Hiemstra, C.; Jones, J.D. Testing for linear and nonlinear granger causality in the stock price-volume relation. J. Financ. 1994, 49, 1639-1664. 
42. Bai, Z.; Hui, Y.; Jiang, D.; Lv, Z.; Wong, W.-K.; Zheng, S. A new test of multivariate nonlinear causality. PLOS ONE 2018, 13, e0185155. [CrossRef]

43. Bai, Z.; Li, H.; Wong, W.-K.; Zhang, B. Multivariate causality tests with simulation and application. Stat. Probab. Lett. 2011, 81, 1063-1071. [CrossRef]

44. Bai, Z.; Hui, Y.; Wong, W.-K.; Zitikis, R. Prospect performance evaluation: Making a case for a non-asymptotic UMPU test. J. Financ. Econ. 2012, 10, 703-732. [CrossRef]

45. Bai, Z.; Li, H.; Liu, H.; Wong, W.-K. Test statistics for prospect and Markowitz stochastic dominances with applications. Econ. J. 2011, 14, 278-303. [CrossRef]

46. Bai, Z.; Li, H.; McAleer, M.; Wong, W.-K. Stochastic dominance statistics for risk averters and risk seekers: An analysis of stock preferences for USA and China. Quant. Financ. 2014, 15, 889-900. [CrossRef]

47. Bai, Z.; Liu, H.; Wong, W.-K. Enhancement of the applicability of markowitz's portfolio optimization by utilizing random matrix theory. Math. Financ. 2009, 19, 639-667. [CrossRef]

48. Bai, Z.; Zhang, B.; Wong, W.-K. Multivariate linear and non-linear causality tests. Math. Comput. Simul. 2010, 81, 5-17. [CrossRef]

49. Chow, S.-C.; Cunado, J.; Gupta, R.; Wong, W.-K. Causal relationships between economic policy uncertainty and housing market returns in China and India: Evidence from linear and nonlinear panel and time series models. Stud. Nonlinear Dyn. Econ. 2017, 22,1-15. [CrossRef]

50. Lean, H.H.; Smyth, R.; Wong, W.-K. Revisiting calendar anomalies in Asian stock markets using a stochastic dominance approach. J. Multinatl. Financ. Manag. 2007, 17, 125-141. [CrossRef]

51. Guo, X.; Wong, W.-K. Multivariate stochastic dominance for risk averters and risk seekers. RAIRO Oper. Res. 2016, 50, 575-586. [CrossRef]

52. Keating, C.; Shadwick, W.F. A universal performance measure. J. Perform. Meas. 2002, 6, 59-84.

53. Guo, X.; Jiang, X.J.; Wong, W.K. Stochastic dominance and omega ratio: Measures to examine market efficiency, arbitrage opportunity, and anomaly. Economies 2017, 5, 38. [CrossRef]

54. Chow, S.-C.; Gupta, R.; Suleman, T.; Wong, W.-K. Long-run movement and predictability of bond spread for brics and piigs: The role of economic, financial and political risks. J. Rev. Glob. Econ. 2019, 8, 239-257. [CrossRef]

55. Chan, R.H.; Chow, S.C.; Guo, X.; Wong, W.-K. Central moments, stochastic dominance, moment rule, and diversification. SSRN Electron. J. 2019. [CrossRef]

56. Ma, C.; Wong, W.-K. Stochastic dominance and risk measure: A decision-theoretic foundation for VaR and C-VaR. Eur. J. Oper. Res. 2010, 207, 927-935. [CrossRef]

57. Alghalith, M.; Guo, X.; Niu, C.; Wong, W.-K. Input demand under joint energy and output prices uncertainties. Asia Pac. J. Oper. Res. 2017, 34. [CrossRef]

58. Guo, X.; Niu, C.; Wong, W.-K. Farinelli and Tibiletti ratio and stochastic dominance. Risk Manag. 2019, 21, 201-213. [CrossRef]

59. Qiao, Z.; Clark, E.; Wong, W.-K. Investors' preference towards risk: Evidence from the Taiwan stock and stock index futures markets. Account. Financ. 2012, 54, 251-274. [CrossRef]

60. Qiao, Z.; Chiang, T.C.; Wong, W.-K. Long-run equilibrium, short-term adjustment, and spillover effects across Chinese segmented stock markets and the Hong Kong stock market. J. Int. Financ. Mark. Inst. Money 2008, 18, 425-437. [CrossRef]

61. Qiao, Z.; Li, Y.; Wong, W.-K. Regime-dependent relationships among the stock markets of the US, Australia, and New Zealand: A markov switching VAR approach. Appl. Financ. Econ. 2011, 21, 1831-1841. [CrossRef]

62. Qiao, Z.; McAleer, M.; Wong, W.-K. Linear and nonlinear causality between changes in consumption and consumer attitudes. Econ. Lett. 2009, 102,161-164. [CrossRef]

63. Qiao, Z.; Wong, W.-K.; Fung, J.K. Stochastic dominance relationships between stock and stock index futures markets: International evidence. Econ. Model. 2013, 33, 552-559. [CrossRef]

64. Chiang, T.C.; Qiao, Z.; Wong, W.-K. New evidence on the relation between return volatility and trading volume. J. Forecast. 2009, 29, 502-515. [CrossRef]

65. Vieito, J.P.; Wong, W.-K.; Zhu, Z.-Z. Could the global financial crisis improve the performance of the G7 stocks markets? Appl. Econ. 2015, 48, 1-15. [CrossRef]

66. Owyong, D.; Wong, W.K.; Horowitz, I. Cointegration and causality among the onshore and offshore markets for china's currency. J. Asian Econ. 2015, 41, 20-38. [CrossRef] 
67. Cheng, A.W.-W.; Chow, N.S.-C.; Chui, D.; Wong, W.-K. The three musketeers relationships between Hong Kong, Shanghai and Shenzhen before and after Shanghai-Hong Kong stock connect. Sustainability 2019, 11, 3845. [CrossRef]

68. Gupta, R.; Lau, C.K.M.; Plakandaras, V.; Wong, W.-K. The role of housing sentiment in forecasting U.S. home sales growth: Evidence from a Bayesian compressed vector autoregressive model. Econ. Res. Ekon. Istraživanja 2019, 32, 2554-2567. [CrossRef]

69. Gupta, R.; Lv, Z.; Wong, W.-K. Macroeconomic shocks and changing dynamics of the U.S. REITs sector. Sustainability 2019, 11, 2776. [CrossRef]

70. Lv, Z.; Chu, A.M.; McAleer, M.; Wong, W.K. Modelling economic growth, carbon emissions, and fossil fuel consumption in china: Cointegration and multivariate causality. Int. J. Environ. Res. Public Health 2019, 16, 4176. [CrossRef]

71. Leung, P.L.; Ng, H.-Y.; Wong, W.-K. An improved estimation to make Markowitz's portfolio optimization theory users friendly and estimation accurate with application on the US stock market investment. Eur. J. Oper. Res. 2012, 222, 85-95. [CrossRef]

72. Li, Z.; Li, X.; Hui, Y.; Wong, W.-K. Maslow portfolio selection for individuals with low financial sustainability. Sustainability 2018, 10, 1128. [CrossRef]

73. Lu, R.; Hoang, V.T.; Wong, W.K. Lump-Sum investing strategy outperform dollar-cost averaging strategy in uptrend markets? Stud. Econ. Financ. 2020. [CrossRef]

74. Lu, R.; Yang, C.-C.; Wong, W.-K. Time diversification: Perspectives from the economic index of riskiness. Ann. Financ. Econ. 2018, 13. [CrossRef]

75. Lam, K.; Liu, T.; Wong, W.-K. A pseudo-Bayesian model in financial decision making with implications to market volatility, under and overreaction. Eur. J. Oper. Res. 2010, 203, 166-175. [CrossRef]

76. Lam, K.; Liu, T.; Wong, W.-K. A new pseudo-bayesian model with implications for financial anomalies and investors' behavior. J. Behav. Financ. 2012, 13, 93-107. [CrossRef]

77. Guo, X.; McAleer, M.; Wong, W.-K.; Zhu, L.-X. A Bayesian approach to excess volatility, short-term underreaction and long-term overreaction during financial crises. N. Am. J. Econ. Financ. 2017, 42, 346-358. [CrossRef]

78. Lean, H.H.; McAleer, M.; Wong, W.K. Market efficiency of oil spot and futures: A mean-variance and stochastic dominance approach. Energy Econ. 2010, 32, 979-986. [CrossRef]

79. Lean, H.H.; McAleer, M.; Wong, W.-K. Preferences of risk-averse and risk-seeking investors for oil spot and futures before, during and after the Global Financial Crisis. Int. Rev. Econ. Financ. 2015, 40, 204-216. [CrossRef]

80. Lean, H.H.; Phoon, K.F.; Wong, W.-K. Stochastic dominance analysis of CTA funds. Rev. Quant. Financ. Account. 2012, 40, 155-170. [CrossRef]

81. Wong, W.-K.; Lean, H.H.; McAleer, M.; Tsai, F.-T. Why are warrant markets sustained in Taiwan but not in China? Sustainability 2018, 10, 3748. [CrossRef]

82. Wan, H.J.; Wong, W.-K. Contagion or inductance? Crisis 1997 reconsidered. Jpn. Econ. Rev. 2001, 52, 372-381. [CrossRef]

83. Clark, E.; Qiao, Z.; Wong, W.-K. Theories of Risk: Testing investor behaviour on the Taiwan stock and stock index futures markets. Econ. Inq. 2006, 54, 907-924. [CrossRef]

84. Ly, S.; Pho, K.-H.; Ly, S.; Wong, W.-K. Determining distribution for the product of random variables by using copulas. Risks 2019, 7, 23. [CrossRef]

85. Ly, S.; Pho, K.-H.; Ly, S.; Wong, W.-K. Determining distribution for the quotients of dependent and independent random variables by using copulas. J. Risk Financ. Manag. 2019, 12, 42. [CrossRef]

86. Hui, Y.C.; Wong, W.K.; Bai, Z.D.; Zhu, Z.Z. A new nonlinearity test to circumvent the limitation of voltrra expansion with application. J. Korean Stat. Soc. 2017, 46, 365-374. [CrossRef]

87. Ng, P.; Wong, W.-K.; Xiao, Z. Stochastic dominance via quantile regression with applications to investigate arbitrage opportunity and market efficiency. Eur. J. Oper. Res. 2017, 261, 666-678. [CrossRef]

88. Guo, X.; Egozcue, M.; Wong, W.K. Production theory under price uncertainty for firms with disappointment aversion. Int. J. Prod. Res. 2020, 1-14. [CrossRef]

89. Guo, X.; Li, G.; McAleer, M.; Wong, W.-K. Specification testing of production in a stochastic frontier model. Sustainability 2018, 10, 3082. [CrossRef]

90. Guo, X.; Levy, H.; Lu, R.; Wong, W.-K. Could omega ratio perform better than sharpe ratio? SSRN Electron. J. 2018. [CrossRef]

91. Ansem, E. Dividends and price momentum. J. Bank. Financ. 2009, 33, 486-494. [CrossRef] 
92. Agmon, T. The Relations among equity markets: A study of share price co-movements in the United States, United Kingdom, Germany and Japan. J. Financ. 1972, 27, 839-855. [CrossRef]

93. Demirer, R.; Gupta, R.; Lv, Z.; Wong, W.-K. Equity return dispersion and stock market volatility: Evidence from multivariate linear and nonlinear causality tests. Sustainability 2019, 11, 351. [CrossRef]

94. Levy, H.; Sarnat, M. International diversification of investment portfolios. Am. Econ. Rev. 1970, 60, 668-675.

95. Niu, C.; Wong, W.-K.; Xu, Q. Kappa ratios and (higher-order) stochastic dominance. Risk Manag. 2017, 19, 245-253. [CrossRef]

96. Zhu, Z.; Bai, Z.; Vieito, J.P.; Wong, W.-K. The impact of the global financial crisis on the efficiency and performance of Latin American stock markets. Estud. Econ. 2019, 46, 5-30. [CrossRef]

97. Ang, A.; Bakaeart, G. Stock return predictability: Is it there. Rev. Financ. Stud. 2007, 20, 651-707. [CrossRef]

Publisher's Note: MDPI stays neutral with regard to jurisdictional claims in published maps and institutional affiliations.

(C) 2020 by the authors. Licensee MDPI, Basel, Switzerland. This article is an open access article distributed under the terms and conditions of the Creative Commons Attribution (CC BY) license (http://creativecommons.org/licenses/by/4.0/). 